\title{
TITLE:
}

\section{OPHIURANS FROM TANABE BAY AND ITS VICINITY, WITH THE \\ DESCRIPTION OF A NEW SPECIES OF OPHIOCENTRUS}

\author{
$\operatorname{AUTHOR}(S)$ : \\ Irimura, Seiichi
}

\section{CITATION:}

Irimura, Seiichi. OPHIURANS FROM TANABE BAY AND ITS VICINITY, WITH THE

DESCRIPTION OF A NEW SPECIES OF OPHIOCENTRUS. PUBLICATIONS OF THE SETO MARINE BIOLOGICAL LABORATORY 1981, 26(1-3): 15-49

\section{ISSUE DATE:}

1981-03-30

URL:

http://hdl.handle.net/2433/176023

RIGHT: 


\title{
OPHIURANS FROM TANABE BAY AND ITS VICINITY, WITH THE DESCRIPTION OF A NEW SPECIES OF OPHIOCENTRUS ${ }^{1)}$
}

\author{
SEIICHI IRIMURA \\ Totsuka Senior High School, Yokohama, Japan
}

With Text-figures $1-9$ and Plate I

The ophiuran fauna of Tanabe Bay, Kii Peninsula, and its vicinity is reported, but still insatisfactorily as seen below. H.L. Clark (1911) dealt with in his monograph of the north Pacific ophiurans, 13 species from off Kii Peninsura and Kitan Channel included in the Albatross collection. Matsumoto (1917) reported in his great monograph of Japanese ophiurans two species from Tanabe Bay. Further, Dr. S. Murakami (1963) reported 18 ophiurans from the waters of the Kii district that were collected by Dr. T. Habe, and Irimura (1969) described a new species, Ophiolepis utinomii, from Tanabe Bay. Thus in all, only 20 species have been known from the waters referred to.

Recently, however, I fortunately had a chance to examine many ophiuran specimens deposited at the Seto Marine Biological Laboratory, Kyoto University. In addition, I paid several visits to the same laboratory and made collecting by myself along the coast of Tanabe Bay or searched for ophiuran specimens among the catches of trawl nets or gill nets, operated in that bay. Further, an ophiuran collection made by Mr. K. Sasaki and another one by Dr. S. Fuse and his group during their ecological survey, both made in the waters under consideration, were submitted to me for my taxonomical studies. Close examination of these collections revealed in them 56 species listed below including a new species and three species new to Japan.

Family Euryalidae

1. Astroceras annulatum Mortensen

2. Astroceras pergamenum Lyman

3. Trichaster flageriffera Martens

Family Gorgonocephalidae

4. Astrocladus coniferus (Döderlein)

5. Astrocladus coniferus var dofleini (Döderlein)

6. Astrocladus annulatum Matsumoto

7. Astrocladus exiguus (Lamarck)

8. Astroglymma sculptum (Döderlein)

9. Astroboa arctos Matsumoto

1) Contributions from the Seto Marine Biological Laboratory, No. 668.

Publ, Seto Mar, Biol, Lab., XXVI (1/3), 15-49, 1981, (Article 2) 
10. Asteroporpa hadracantha H.L. Clark

Family Ophiacanthidae

11. Ophiacantha levispina Lyman

Family Ophiactidae

12. Ophiactis savignyi (Müller \& Troschel)

13. Ophiactis affinis Duncan

14. Ophiactis macrolepidota Marktanner-Turneretscher

15. Ophiactis modesta Brock

16. Ophiactis profundi Lütken \& Mortensen

17. Ophiodaphne marterna Koehler

18. Ophiopholis brachiactis H.L. Clark

Family Amphiuridae

19. Amphioplus japonicus (Matsumoto)

20. Amphioplus megapomus H.L. Clark

21. Amphipholis japonica Matsumoto

22. Amphiura (Fellaria) vadicola (Matsumoto)

23. Amphiura pachybactra Murakami

24. Ophiocentrus tokiokai sp. nov.

Family Ophiotrichidae

25. Ophiothrix exigua Lyman

26. Ophiothrix koreana Duncan

27. Ophiothrix ciliaris (Lamarck)

28. Ophiothrix marginata Koehler

29. Ophiothrix (Acanthophiothrix) purpurea Martens

30. Ophiothrix (Keystonea) nereidina (Lamarck)

31. Macrophiothrix longipeda (Lamarck)

32. Ophiothela danae Verrill

33. Ophiogymna elegans Ljungman

34. Ophiogymna fulgens (Koehler)

35. Ophiomaza cacaotica Lyman

Family Ophiuridae

Subfamily Ophiurinae

36. Stegophiura sladeni (Duncan)

37. Stegophiura sterea (H.L. Clark)

38. Ophiura kinbergi (Ljungman)

39. Aspidophiura forbesi (Duncan)

Subfamily Ophiolepidinae

40. Ophiomusium simplex Lyman

41. Ophiomusium scalare Lyman

42. Ophiomusium trychnum H.L. Glark

43. Ophioplocus japonicus H.L. Glark

44. Ophiolepis utinomii Irimura

45. Ophiozonella longispina (H.L. Clark) 
46. Ophiozonella projecta (Koehler)

47. Ophiozonella oedilepis (Murakami)

Family Ophiodermatidae

48. Ophiarachnella gorgonia (Müller \& Troschel)

49. Ophiarachnella differens Murakami

50. Ophiarachna incrassata (Lamarck)

51. Ophiarachna ohshimai Murakami

52. Pectinura anchista H.L. Clark

Family Ophiocomidae

53. Ophiocoma dentata Müller \& Troschel

54. Ophiomastix mixta Lütken

Family Ophionereidae

55. Ophionereis dubia (Müller \& Troschel)

56. Ophionereis variegata Duncan

Before going further, I want to express my sincere thanks to the late Dr. $H$. Utinomi, Professor Emeritus, Kyoto University, for his help during my works in the vicinity of the Seto Marine Biological Laboratory and for his efforts of identifying some alcyonaceans as the hosts of certain ophiurans. I also extend my gratitude to the staff of the Seto Marine Biological Laboratory, especially to Dr. S. Fuse and his group, for their generosity in submitting the valuable materials to my disposal. Further, I have to record here with my hearty thanks the kindness of Mr. K. Sasaki, who offered me his collection of ophiurans, and of Dr. David L. Pawson, U.S. National Museum, who lent out some important specimens for the present study. Lastly, I am very grateful to Dr. T. Tokioka for his kindness in reading the manuscript.

\section{Taxonomical Notes \\ Family Euryalidae Gary, 1840 \\ 1. Astroceras annulatum Mortensen}

(Jap. name: Mutsu-ude-tsuno-mozuru)

(Pl. I, figs. 2 \& 3)

Asteroceras pergamena, Matsumoto, 1917, p. 35, fig. 7b. (non Lyman 1879).

Asteroceras annulatum Mortensen, 1933, p. 47, fig. 32, pl. V, figs. 20-25; Murakami, 1944 b, p. 261; Irimura, 1963, p. 39, pl. I, fig. 2.

Material examined: Off Sakai, Nov. 10, 1922 (Oph. 32)*; off Minabe, by fishing net, March 22, 1971 (Oph. 81); off Sakai, by fishing net, Oct. 25, 1971 (Oph. 98).

Distribution: Urage Channel, Sagami Bay, Off Amakusa, Near Goto Is.

* Oph. denoted: specimen number at the museum of the Seto Marine Biological Laboratory. 
Remarks: This species is always found clinched to the colony of such coelenterates as alcyonaceans or gorgonaceans. Murakami (1944 b) found this species on $M e$ litodes sp. and Irimura (1969) on Acanthogorgia japonica and Dendronephthya sp. Of the specimens from Tanabe Bay, Oph. 81 was found on Plumarella sp., Oph. 96 on Euplexaura erecta, and Oph. 98 on Plumarella sp. (pl. I. Fig. 2).

Although Matsumoto (1917) and Murakami (1944 b) noted that this species was six-armed, Oph. 96 and 98 contain a few specimens five-armed (pl. I. Fig. 3). Color: yellowish white with light pink to reddish purple patches on the dorsal disk and annulations of the same color on arms.

\section{Astroceras pergamenum Lyman}

(Jap. name: Tsuno-mozuru)

Astroceras pergamena Lyman, 1879, p. 62, pl. XVIII, figs. 478-480: 1882, p. 284, pl. XXXIV, figs. 1-5;

Koehler, 1904a, p. 159; H.L. Clark, 1911, 284; Döderlein, 1911, p. 61, pl. VI, figs. 4-4b, pl.

VIII, fig. 13; Matsumoto, 1917, p. 35; Döderlein, 1927, p. 79; Koehler, 1922, p. 33, pl. 93, fig.

3: 1930, p. 24; Chang, Liao \& Wu, 1962, p. 61, pl. 4, fig. 4; Irimura, 1969, p. 39.

Astroceras pergamenum Mortensen, 1933a, p. 42, figs. 29-31.

Material examined: Off Sakai, by fishing net, Dec. 28, 1970 (Oph. 99).

Distribution: Sagami Bay, Suruga Bay, Enshu-nada, Amakusa, Goto Is., off Yakushima, off Hainan Is., Timor, Mindanao, Jolo, Kei Is.

Remarks: Oph. 99 was found clinched to a species of Plumarella. Color: brown.

\section{Trichaster flageriffera Martens}

(Jap. name: Tsurutako-hitode)

Trichaster flagelifer Martens, 1877, p. 87; Döderlein, 1930, p. 392; Chang, Liao \& Wu, 1962, p. 63; Irimura, 1969, p. 39.

Trichaster elegans Ludwig, 1878, p. 59, figs. 1-9; Matsumoto, 1917, p. 38, fig. 8, pl. 11, figs. 7 \& 8; Döderlein, 1927, p. 30; Murakami, 1944 b. p. 262.

Material examined: Off Seto, by fishing net, Apr. 22, 1951 (Oph. 10). Other records from Tanabe Bay were noted by Matsumoto (1917).

Distribution: Amakusa, Tsingtao, Indian Ocean.

\section{Family Gorgonocephalidae Ljungman, 1868}

\section{Astrocladus coniferus (Döderlein)}

(Jap. name: Seno-tezuru-mozuru)

Astrophyton coniferum Döđerlein, 1902, p. 325.

Astrophyton cormutum H.L. Clark, 1911, p. 292.

Astrocladus coniferus Döderlein, 1911, pp. 46 \& 76, pl. II, figs. 7 \& 7a, pl. IV. figs. 1-3a, pl. VI, figs. 5-6a \& 16; Matsumoto, 1917, p. 77, fig. 23; Murakami, 1944b, p. 262; Irimura, 1969, p. 39. 
Material examined: Okino-shima, Apr. 27. 1952 (Oph. 39); Seto, June 23, 1952 (Oph. 44); Tohshima, June 22, 1952 (Oph. 46).

Distribution: Sagami Bay, Suruga Bay, off Tosa, Kagoshima, Japan; Peter the Great Bay; Fusan, Korea; Colnett Strait (=Tanega-shima Strait); East China Sea; Indian Ocean.

Remarks: This species lives in association with alcyonaceans.

Color: Very variable; mainly brown; sometimes yellow, gray or dark purple.

\section{Astrocladus coniferus var. dofleini (Döderlein)}

(Jap. name: Ibo-tezuru-mozuru)

Astrocladus dofleini Döderlein, 1910, p. 256: 1911, p. 41, fig. 9, pl. II, figs, 1-4, pl. IV, figs. 15-15b. Astrocladus coniferus var. doffeini Matsumoto, 1917, p. 77; Irimura, 1969, p. 2.

Material examined: Tanabe Bay, Oct. 9, 1937 (Oph. 45); off Sakai, by fishing net, June 16, 1954 (Oph. 55).

Distribution: Sagami Bay, Amakusa.

Remarks: Color: very variable; real black, dark purple, brown, or deep yellow. Number and form of tubercles on the dorsal disk and dorsal arms are very variable too.

\section{Astrocladus annulatum Matsumoto}

(Jap. name: Fushi-tezuru-mozuru)

Astrosladus annulatum Matsumoto, 1915, p. 56: 1917, p. 75, fig. 22.

Material examined: Seto, Nov. 10, 1922 (Oph. 32); Seto, Apr. 11, 1952 (Oph 43).

Distribution: Misaki, Sagami Bay.

\section{Astrocladus exiguus (Lamarck)}

(Jap. name nov: Koboshi-tezuru-mozuru)

Euryale exiguus Lamarck, 1816, p. 539.

Astrophyton exiguus Müller \& Troschel, 1842, p. 125; Lyman, 1882, p. 257, pl. XLVII, fig. 1.

Gorgonocephalus cornutum Koehler, 1898, p. 368, pl. IX, figs. 80 \& 81: 1899, p. 73, pl. XII, figs. 95 \& 96, pl. XIII, fig. 98.

Astrophyton cornutum Koehler, 1905, p. 127, pl. XIII, fig. 1, pl. XVIII, fig. 2.

Astrocladus exiguus Döderlein, 1911, p. 76, pl. IX, fig. 6; H.L. Clark, 1915, p. 1 87; Döderlein, 1927, p. 34, pl. V, fig. 9; Kochler, 1930, p. 34, pl. IV, figs. 1 \& 2; Chang, Liao \& Wu, 1962, p. 59, pl. I, figs. 1 \& 2; A.M. Clark \& Rowe, 1971, pp. 78 \& 92, fig. 21; Cherbonnier \& Guille, 1978, p. 11, pl. II, figs. $1 \& 2$.

Material examined: Tanabe Bay, by fishing net, Oct. 9, 1937 (Oph. 49).

Distribution: Colnett Strait (=Tanega-shima Channel), Japan; Indo-West Pacific area. 


\section{Astroglymma sculptum (Döderlein)}

(Jap. name: Aka-tezuru-mozuru)

Astrophyton sculptum Döderlein, 1896, p. 299, pl. XVIII, figs. 29-29b.

Astrodactylus sculptum Döderlein, 1911, p. 56, figs. 13a \& 13b.

Astroglymma sculptum Döderlein, 1927, pp. 49 \& 96, p!. I, figs. 3 \& 4, pl. V, fig. 13; Mortensen, 1934, p. 5, pl. VI; Murakami, 1944b, p. 263, fig. 1; Chang, Liao \& Wu, 1962, p. 60, pl. III, figs. 1 \& 2; Irimura, 1969, p. 40.

Material examined: Seto, March 15, 1941 (Oph. 42).

Distribution: Amakusa; Hong kong; Hainan Is., China; Kei Is.

Remarks: Color: rosy red.

\section{Astroboa arctos Matsumoto \\ (Jap. name: Samehada-tezuru-mozuru)}

Astroboa nuda Matsumoto, 1915, p. 57: 1917, p. 80, fig. 24; Murakami, 1944b, p. 262, pl. I, figs. 2 \& 3; Irimura, 1969, p. 40.

Material examined: Banshozaki reef, June 14, 1968 (Oph. 75).

Distribution: Misaki, Sagami Bay.

Remarks: Color: usually brown.

\section{Asteroporpa hadracantha H. L. Clark}

(Jap. name: Shigeto-mozuru)

$$
\text { (Pl. I, Figs. } 1 \text { \& 2) }
$$

Asteroporpa hadracantha H.L. Clark, 1911, p. 280, fig. 142; Matsumoto, 1917, p. 67, fig. 17; Chang, Liao \& Wu, 1962, p. 57, fig. 2.

Material examined: Off Minabe, by fishing net, March 22, 1971 (Oph. 84); off Yuzaki, ca. $100 \mathrm{~m}$ deep by fishing net, Oct. 23, 1971 (Oph. 95); off Sakai, by fishing net, Dec. 28, 1970 (Oph. 97).

Distribution: Uji-shima, Kagoshima Pref, Sagami Bay, Omaezaki, Japan; East China Sea; Hainan Is., China.

Remarks: This small and simply armed basket-star (Oph. 84. 95. 97) is found clinched to the gorgonacean Plumarella spinosa. Oph. 97 was collected together with many specimens of Astroceras annulatum from the same host. (P1. I, fig. 2) Color: dark purple.

\section{Family Ophiacanthidae Perrier, 1891}

\section{Ophiacantha levispina Lyman}

(Jap. name: Togeude-kumohitode)

Ophiacantha levispina Lyman, 1878, p. 147, pl. X, fig. 277: 1882, p. 196, pl. XXV, figs. I-3; H.L. Clark, 1911, p. 198; Matsumoto, 1917, p. 115; J'yakonov, 1949, p. 52. 
Material examined: Off Minabe, 100-200 m deep, by fishing net, March 10, 1944 (Oph. 53).

Distribution: Japan Sea, Pacific coast of Japan, East China Sea, Malay Archipelago.

\section{Family Ophiactidae Matsumoto, 1915}

\section{Ophiactis savignyi (Müller \& Troschel)}

(Jap. name: Chibi-kumohitode)

Ophiolepis savignyi Müller \& Troschel, 1842, p. 95.

Ophiolepis six-radia Grube, 1857, p. 343.

Ophiactis six-radia Lìtken, 1853, p. 126; Lyman, 1856, p. 115.

Ophiactis krebsii Liitken, 1853, p. 111 ; Duncan, 1879, p. 465.

Ophiactis reinhardti L.utken, 1853, p. 161, pl. III, fig. 7 .

Ophiactis savignyi Lyman, 1882, p. 115; Lutken \& Mortensen, 1899, p. 140; Koehler, 1905, p. 26; Matsumoto, 1917, p. 158, fig. 39; Murakami, 1942, p. 8: 1943a, p. 167: 1944b, p. 264: Murakami. 1963, p. 174; Irimura, 1969, p. 40. A.M. Clark \& Rowe, 1971, p. 103, fig. 31b; Devaney, 1974, p. 134; Liao, 1978, p. 72. fig. 2; Cherbonnier \& Guille, 1978, p. 125, fig. 57; Irimura, 1979, p. 2.

Material examined: Seto, littoral zone, March 11, 1944. (Oph. 3); Hatake-jima, littoral zone, June 29, 1968. (Oph. 56); off Minabe, by fishing net, June 6, 1971 (Oph. 87). Other record, Shirahama, (Murakami 1963)

Distribution: West of Sado Island (Japan Sea), Sagami Bay, Japan; world tropical and subtropical coasts.

Remarks: This small six-armed brittle star is found very commonly in crevices, under shells or boulders, at kelp roots, or on sponges in the littoral zone of Tanabe Bay. Oph. 87 was found clinched to a sponge, Callyspongia confoederata. Color: grayish green on the dorsal disk, darker and lighter annular bands alternating on dorsal arms, and three white spots on the outer margin of each dorsal arm plate. It has been erroneously reported that this species has 5 arms in juvenile stages, but none of such specimens have ever been found so far.

\section{Ophiactis affinis Duncan}

(Jap. name nov.: Kusairo-chibi-kumohitode)

Ophiactis affinis Duncan, 1879, p. 469, pl. 10, fig. 23, pl. 11, fig. 24; Lyman, 1882, p. 121; Koehler, 1898, p. 72: 1905, p. 26; H.L. Clark, 1915, p. 266: Matsumoto, 1917, p. 155; Koehler, 1922, p. 186, pl. 62, fig. 6, pl. 63, fig. 5: 1930, p. 121; Hayashi, 1975, p. 6.

Material examined: Kabego-zaki in Gobo, $4 \mathrm{~m}$ deep, under boulder on rocky bed, May 4, 1978; Koza in Gobo, $4 \mathrm{~m}$ deep, on rocky bed, May 3, 1978; Kamaiwa-nohana in Gobo, $4 \mathrm{~m}$ deep, on rocky slope, May 4, 1978; Shimo-kusui in Gobo, $4 \mathrm{~m}$ deep, on rocky bed, May 4, 1978.

Distribution: Coasts of Wakayama Prefecture, Korea Strait, Philippine Sea, Kei Is., Banda Sea. 
Remarks: Color: green with dark patches on the dorsal disk and dark annulations on dorsal arms. Arm spines five in basal arm. Hayashi (1975) reported that this species was found clinched to the tropical star fish, Acanthaster planci, at Shiono-misaki, Wakayama Prefecture. A.M. Clark and Rowe (1971) overlooked this species from their recent monograph.

\section{Ophiactis macrolepidota Marktanner-Turneretscher}

(Jap. name: Dairin-chibi-kumohitode)

Ophiactis macrolepidota Marktanner-Turneretshcer, 1887, p. 298, pl. XII, figs. 12 \& 13; Döderlein, 1898, p. 484, pl. 37, figs. 1 \& 1a; Matsumoto, 1917, p. 155, fig. 37; H.L. Clark, 1946, p. 209; A.M. Clark, 1965, p. 41.

Material examined: Ono-zaki in Gobo, $3 \mathrm{~m}$ deep, on rocky slope, May 1, 1978; Umaiwa in Gobo, $3 \mathrm{~m}$ deep, under boulder, May 2, 1978; Koza in Gobo, $3 \mathrm{~m}$ deep, on rocky bed, May 3, 1978.

Distritution: Uraga Channel, Sagami Bay, Tsushima, Japan; Sydney, Amboina. Remarks: A.M. Clark and Rowe (1971) suggested that this species might fall within the species-group of $O$. brachiura, $O$. parba, O. delicata, O. lymani, and $O$. acosmeta. The present identification is induced provisionally by the keys provided by Matsumoto (1917), as the validity of this species is not yet settled decidedly.

\section{Ophiactis modesta Brock}

(Jap. name: Hyotan-chibi-kumohitode)

Ophiactis modesta Brock, 1888, p. 482; Döderlein, 1896, p. 285, pl. XIV, figs. 5-5b; Kochler, 1904b, p. 63, figs. 10 \& 11; Matsumoto, 1917, p. 156, fig. 38; Murakami, 1943a, p. 167: H.L. Clark, 1949, p. 33; 1963, p. 173; Irimura, 1969, p. 40; Liao, 1978, p. 72; A.M. Clark \& Rowe, 1971, p. 105.

Record in Tanabe Bay: Seto, (Murakami 1963).

Distribution: Misaki, Amakusa, Japan; Hawaii, Palao, Amboina, Xisha Is., Thursday Is., Australia.

Remarks: Chebronnier \& Guille (1978) synonymized $O$. modesta into $O$. savignyi by emphasizing the fact that both species are considerably variable in number of oral papillae and arm spines. This view seems, however, to more crucial comparative studies on the two species. The present identification was based on the keys by Matsumoto (1917).

\section{Ophiactis profundi Lütken \& Mortensen}

(Jap. name: Ara-uroko-kumohitode)

Ophiactis profundi Lütken \& Mortensen, 1899, p. 140, pl. VI, figs. 4-6; Kochler, 1922, p. 192, pl. 63, fig. 8; Murakami, 1963, p. 173.

Ophiactis pteropoma H.I. Clark, 1911, p. 134, fig. 50; Matsumoto, 1917, p. 154, pl. III, fig. 9. 
Record in Tanabe Bay: Off Minabe (Murakami 1963).

Distribution: Uraga Channel, off Misaki, off Hino-misaki, off Kii, Japan Sea, Tsugaru Channel.

\section{Ophiodaphne marterna Koehler}

(Fig. 1)

(Jap. name nov.: Daki-kumohitode)

Ophiodaphne marterna Koehler, 1930, p. 129, pl. XVI, figs. 3 \& 8; H.L. Clark, 1938, p. 270; 1939, p. 82; A.M. Clark \& Rowe, 1971, p. 103, fig. 32b. Devaney, 1974, p. 135.

Material examined: Off Minabe, by fishing net, Dec. 28, 1970 (SMBL Rare 296). Distribution: Kei Is., Southeastern Polynesia, North Australia; Arabian coasts. Remarks: This species is recorded here for the first time in Japan. A larger specimen, supposedly female, and a smaller "male" were found at the oral part of Clypeaster reticulatus, clinched to each other in the state of mouth to mouth. The larger one is ca. $4 \mathrm{~mm}$ in disk diameter and ca. $5 \mathrm{~mm}$ in arm length, while the smaller one only ca. $1 \mathrm{~mm}$ in disk diameter and ca. $3 \mathrm{~mm}$ in arm length. Koehler (1930) described that there are four arm spines in this species, but the present specimens have each six arm spines. Oral plates are longer and inner oral papillae are smaller in the present specimens than in the specimens illustrated by A.M. Clark \& Rowe (1971). In the present specimens, inner oral papillae are scale-like and not divergent at the tip; maxillae are visible and lowest teeth are square in shape and not divergent at the tip, either.

\section{Ophiopholis brachyactis H. H. Clark}

(Jap. name: Juzuhimo-kumohitode)

Ophiopholis brachyactis H.L. Clark, 1911, p. 117, fig. 44; Matsumoto, 1917, p. 163, fig. 42; Murakami, 1942, p. 9: 1963, p. 174 .

Material examined: Hatake-jima, Apr. 25, 1928 (Oph. 12); off Minabe, by fishing net, 100-200 m deep, March 12, 1944 (Oph. 51). Other record, Off Minabe (Murakami 1963).

Distribution: Uraga Channel, Sagami Bay, Suruga Bay, off Kii, Kagoshima Bay, Japan Sea, East China Sea.

Remarks: Color: vermilion.

Family Amphiuridae Ljungman, 1867

19. Amphioplus japonicus (Matsumoto)

(Jap. name: Kaki-kumohitode) 
Ophiophragmus japonicus Matsumoto, 1915, p. 70: 1917, p. 183, fig. 48, pl. IV, fig. 3; Koehler, 1930, p. 111; Matsumoto, 1941, p. 333, fig. 2; Murakami, 1943b, p. 230; 1944b, p. 264.

Amphioplus japonicus H.L. Clark, 1918, p. 271; Murakami, 1963, p. 175; Irimura, 1969, p. 41.

Record in Tanabe Bay: Tanabe Bay (Murakami, 1963).

Distribution: West of Mutsu Bay, bay of the Pacific coast of Japan, Gulf of Siam; Kei Is.
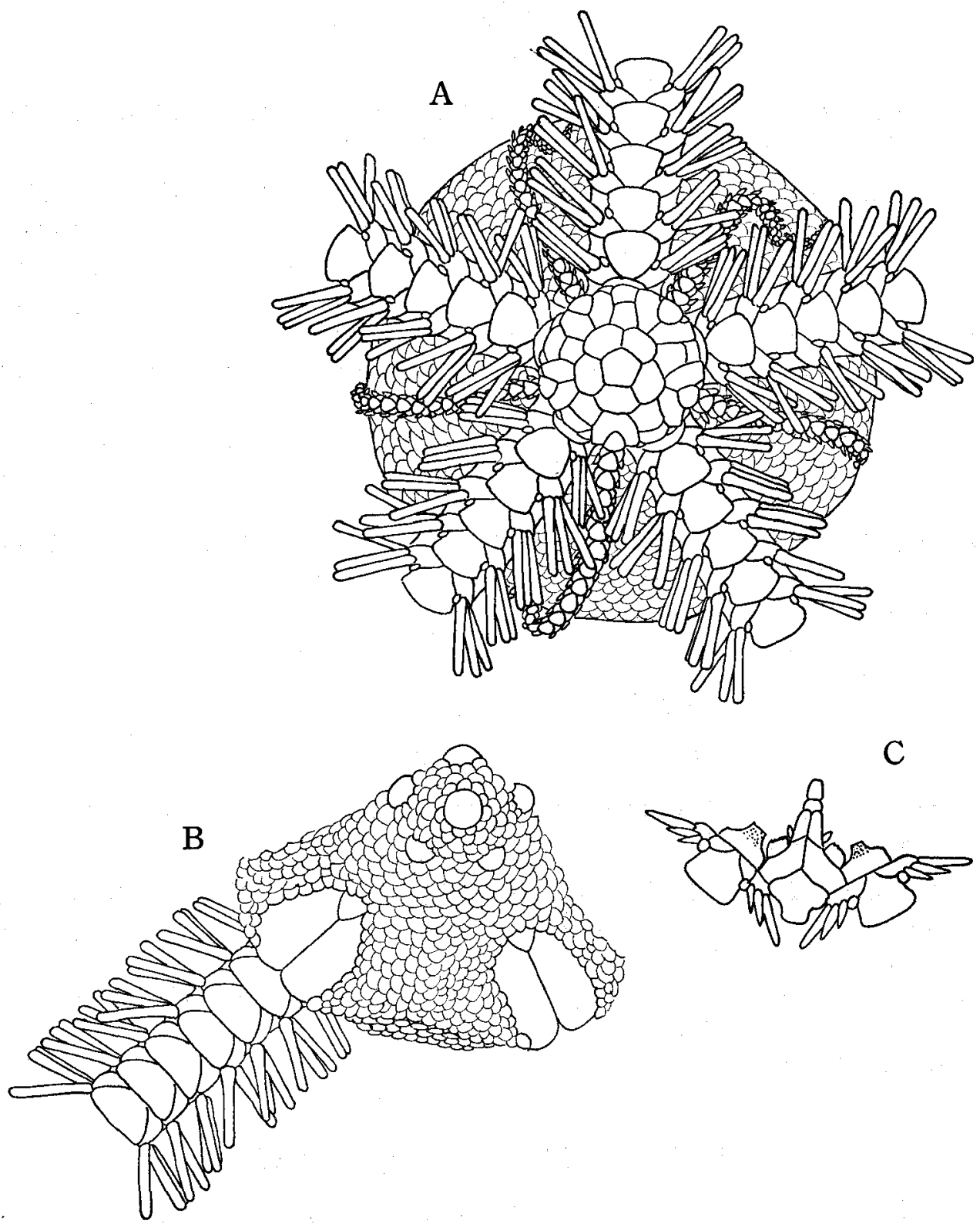

$\mathrm{C}$

Fig. 1. Ophiodaphne marterna. A: ventral view of female with superimposed male; B: dorsal view of female; $\mathrm{C}$ : single jaw and 1st and 2 nd ventral arm plates of female. 


\section{Amphioplus megapomus H. L. Clark}

(Jap. name: Miyadi-kumohitode)

(Fig. 2)

Amphioplus megapomus H.L. Clark, 1911, p. 170; Matsumoto, 1917, p. 170.

Amphioplus miyadii Murakami, 1943c, p. 228, fig. 2: 1963, p. 175.

Material examined: Tanabe Bay, by dredge, Apr. 9, 1951 (Oph. 9); Tsuna-shirazu, by fishing net, Aug. 22, 1929 (Oph. 17).

Distribution: West of Sagami Bay, bays on the Pacific coast of Japan; Japan Sea. Remarks: H.L. Clark (1911) described A. megapomus on the holotype from the Kii Channel but without giving any figures. His specimen was lack of the dorsal disk. On the other hand, Murakami (1943 c) reported A. miyadii from several Japanese bays. As it seems to me that Murakami's descriptions and figures of A. miyadii coincide with H.L. Clark's descriptions, the holotype of Amphioplus megapomus which was lent out from the U.S. National Museum by the courtesy of Dr. D. Pawson, was examined closely and this led me to the conclusion that there were no differences between the type and Murakami's species. Amphioplus miyadii is, therefore, synonymized here with Amphioplus megapomus.

A

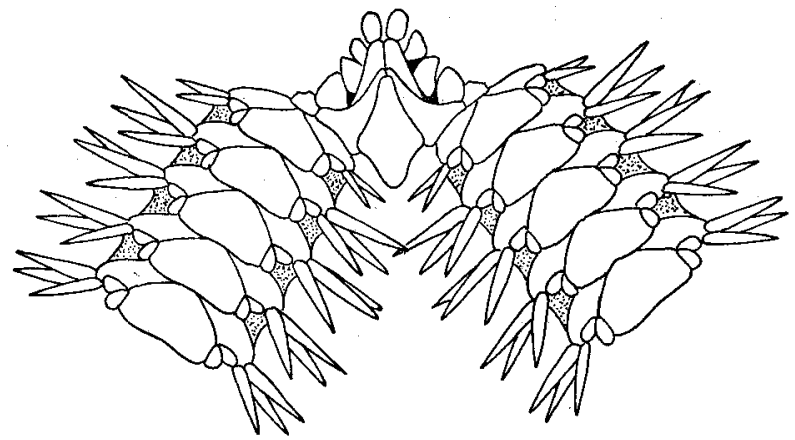

B

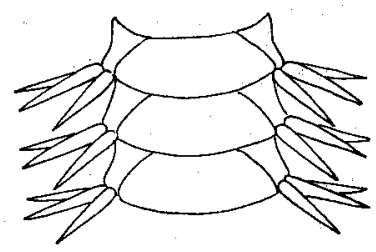

Fig. 2. Holotype of Amphioplus megapomus (U.S.N.M. 25633). A: vental view; B: dorsal arm plates.

\section{Amphipholis japonica Matsumoto}

(Jap name: Iso-komochi-kumohitode)

Amphipholis japonica Matsumoto, 1915, p. 71: 1917, p. 186, fig. 49; Murakami, 1942, p. 10: 1944b, p. 265: 1963, p. 175; Irimura, 1969, p. 41; 1979, p. 3.

Material examined: Seto, under boulder in littoral zone, July 31, 1968 (oph. 77); Ono-zaki in Gobo, $3.5 \mathrm{~m}$ deep, on rocky slope, May 1, 1978; Koza in Gobo, $3 \mathrm{~m}$ deep, on rocky bed, May 3, 1978; Uno-shima in Grobo, $3 \mathrm{~m}$ deep, on rocky bed, May 3, 1978; Shimo-kusui in Gobo, $4 \mathrm{~m}$ deep, on rocky bed, May 4, 1978.

Distribution: Bays on Japanese coasts. 


\section{Amphiura (Fellaria) vadicola (Matsumoto)}

(Jap. name: Udenaga-megane-kumohitode)

Ophionephthys phalerata Marktanner-Turneretscher, 1887, p. 301. (non Lyman 1874).

Amphiura vadicola Matsumoto, 1915, p. 71 : 1917, p. 211, fig. 58.

Amphiura (Fellaria) vadicola A.M. Clark, 1970, p. 76.

Material examined: Hatake-jima, on muddy bottom in littoral zone, June 15, 1974 (Oph. 88); between Tohshima and Engetsu-to, by dredge, $22 \mathrm{~m}$ deep, Nov. 1977 (Oph. 100).

Distribution: Off Otaru, Kagoshima Bay, Japan; Korea; Tsingtao, China.

Remarks: Oph. 88 differs a little from the specimens described by Matsumoto (1917) in the following characters. Radial shields contact each other, not pear-seedshaped but elongate, with basal edges rounded but distally rectangular, and surrounded by much fewer scales. Dorsal arm plates in the basal joints are not very small and contact each other. First ventral arm plates are not very small and longer than wide. In the figure given by Matsumoto, the ventral arm plates within the disk are seven, but there are fourteen in the present specimens. Color: brown.

\section{Amphiura pachybactra Murakami}

(Jap. name: Kakutoge-kumohitode)

Amphiura pachybactra Murakami, 1942, p. 17, fig. 7.

Material examined: Ono-zaki in Gobo, $5 \mathrm{~m}$ deep, under boulder, May 1, 1978; Kabego-zaki in Gobo, $4 \mathrm{~m}$ deep, under boulder on rocky bed, May 4, 1978; Unoshima, $5 \mathrm{~m}$ deep, under boulder on rocky bed, May 3, 1978.

Distribution: Tip of Izu Peninsula.

Remarks: Color: blue dorsally, arms with annulations consisting of darker and lighter bands.

\section{Ophiocentrus tokiokai sp. nov.}

(Jap. name nov.: Tokioka-kumohitode)

(Fig. 3)

Holotype: SMBL-Type 315, deposited at the museum of the Seto Marine Biological Laboratory. Type locality: Rocky shore.

Type locality: Rocky shore of Kamaiwa-no-hana in Gobo, Wakayama Prefecture. Etymology: This species name commemorates the retirement of Prof. Tokioka who contributed in great deal of marine planktonic and benthic fauna in Japanese and adjacent area.

Description: Disk diameter $7 \mathrm{~mm}$. Arms all broken, but probably ten times as long as disk diameter or more. Disk roundish pentagonal, with concave interradial and 


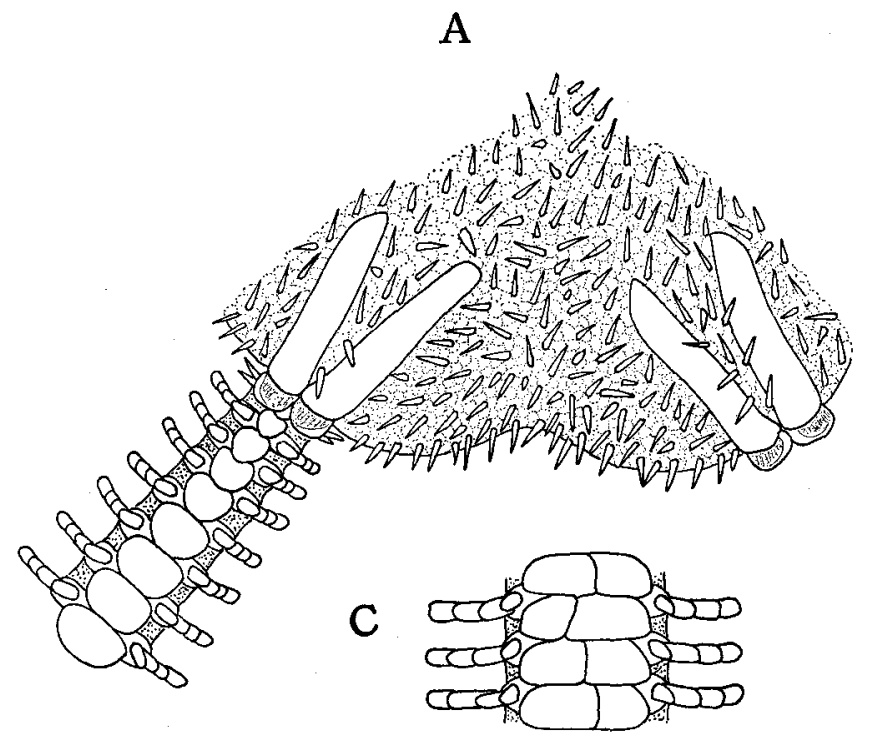

B

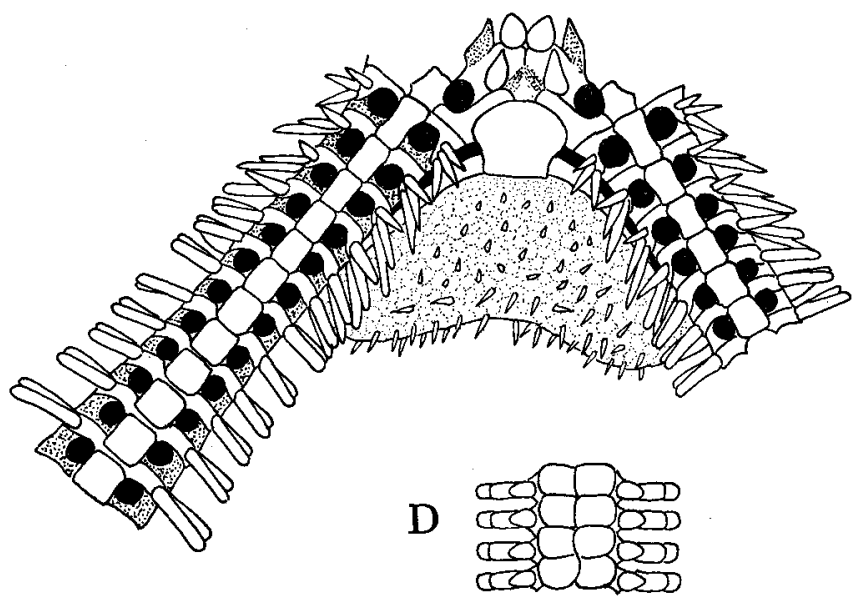

Fig. 3. Ophiocentrus tokiokni. A: dorsal view; B: ventral view; G: dorsal arm plates, ca. thirtieth arm joints; D : dorsal arm plates, ca. fiftieth arm joints.

covered with a very thin skin furnished many slender tapering spinules scattered on the surface; the fine scales in interradial area become visible by drying. Radial shields narrow and long, half as long as disk radius, considerably separated basally but converging distally in an acute angle to a slight touch at the distal end.

The oral shields subquadrate as long as wide, roundly expanded proximally but truncated distally. Madreporite considerably large. Adoral shields separated from each other, with a distal lobe between the first ventral arm plate and the adjacent lateral arm plate. Oral plates long, sunken distally. Infradental papillae large, squarish, but rounded at corners. Distal papillae large, flat, arisen from 
the proximal end of the adoral shield. Interbrachial space ventrally covered with a thin skin furnished with very fine scales and many spinules scattered on the surface. Genital slit long, reaching the oral shield.

Arm long, flat, and flexible; the basal part narrow but distally abruptly increase the width. Surface of dorsal arm plates very rough. First to fourth dorsal arm plates are as long as wide and deeply concave at the proximal border, but the following ones become elliptic and broader than long; the plates distal to the twelfth free segments are about two times as wide as long and those distal to the thirtieth free segment are split longitudinally into two pieces.

First ventral arm plates hexagonal, as long as wide; second rectangular, with rounded corners, about two times as long as wide; third to seventh rectangular and longer than wide. The ventral plates of the following free segments become tetragonal, with rounded corners, as long as wide, and separated from each other; the plates distal to the fifteenth free segment are pentagonal and broader than long.

Lateral arm plates with six flat spines, the uppermost one is the shortest and the lowermost is the longest. Distally to about the sixteenth arm segment, however, the spines decrease to five. Tentacle pore large, without any tentacle scales. Remarks: There is not known within the genus Ophiocentrus any species that has the large radial shield half as long as the disk radius and the divided dorsal arm plates excluding the basal arms.

The present new species resembles $O$. dilatatus (Koehler) recently redescribed and figured by Cherbonnier \& Guille (1978) and recorded from Indonesia, Maldive Is., North Australia, Mozambique and Madagascar, in having fewer flat arm spines, of which the dorsalmost one is the shortest. The Koehles's species is, however, easily distinguishable from the present new species by its shorter radial shield, undivided arm plates and different shape of the oral shield. Another allied species is O. inaequalis (H.L. Clark) reported from Hong-kong and Madagascar, though it differs from the present new species not only in its shorter radial shield and undivided dorsal arm plate, but also in having more spines which are divergent at the tip.

\section{Family Ophiotrichidae Ljungman, 1866}

\section{Ophiothrix exigua Lyman}

(Jap. name Nagatoge-kumohitode)

$$
\text { (Pl. I, fig. 4) }
$$

Ophiothrix exigua Lyman, 1874, p. 236, pl. IV, figs. 24-26: 1882, p. 217; Koehler, 1905 p. 86, pl. IX, figs. 15 \& 16: 1905b, p. 458: 1907, p. 332; H.L. Clark, 1915, p. 272; Koehler, 1922, p. 228, pl. 40, figs. 1-4: 1930, p. 139; Mortensen, 1934, p. 10; H.L. Clark, 1938, p. 273; A.H. Clark, 1952, p. 293; A.M. Clark, 1967b, p. 647; A.M. Clark \& Rowe, 1971, p. 110; Cherbonnier \& Guille, 1978, p. 140, pl. V, figs. 5 \& 6, figs. 61, 3 \& 4; Guille \& Jangoux, 1978, p. 61. Ophiothrix koreana Duncan, 1879, p. 473, pl. XI, figs. 28-32. (par) 
Ophiothrix stelligera Marktanner-Turnerescher, 1887, p. 310 (non Lyman).

Ophiothrix marenzelleri Koehler, 1904b, p. 103, figs. 77 \& 78; Matsumoto, 1917, p. 220: 1918, p. 478;

Koehler, 1922, p. 248, pl. 39, figs. 3-5; Matsumoto, 1941, p. 342, fig. 8; Murakami, 1943c, p. 233: 1944b, p. 267: 1963, p. 176; A.M. Clark, 1967b, p. 647; Irimura, 1969, p. 43: 1979, p. 4. Ophiothrix hylodes H.L. Clark, 1911, p. 263, fig. 130.

Material examined: Hatake-jima, littoral zone, under boulder, Apr. 2, 1938 (Oph. 23). off Minabe, by fishing net, ca. $50 \mathrm{~m}$ deep, June 6, 1971 (Oph. 85). off Minabe, by fishing net, ca. $50 \mathrm{~m}$ deep, June 6, 1971 (Oph. 86). Other records from Tanabe Bay were noted by Murakami (1963).

Distribution: West of Mutsu Bay to Indo-West Pacific area.

Remarks: Lyman (1874) erected Ophiothrix exigua based on the specimens from the Philippine Sea. After that, Koehler (1905) reexamined the specimens from Banda Sea adopting Lyman's name, and many subsequent authors reported this species from all area of Indo-West Pacific. On the other hand, Koehler (1904) recorded O. marenzelleri based on the specimens from Japan, and Matsumoto (1917) included it in the keys to Japanese species of Gen. Ophiothrix. Therefore Murakami and Irimura reported it in the neighboring seas of Japan.

But Koehler's description of $O$. marenzelleri differs nothing from Lyman's description of $O$. exigua, except characters of ventral disk. LyMAN reported ventral disk "Below, the interbrachial spaces are naked". Koehler (1905) amended Lyman's diagnosis of $O$. exigua regarding to ventral disk that, "cette face n'est qu'en partie nue, car elle offre, non pas seulement sur son bord mais sur un petit espace triangulaire dans sa région distall". So, it is just coincident with diagnosis of $O$. marenzelleri. Therefore, I incline to believe that, Ophiothrix marenzelleri is a junior synonym of $O$. exigua. A.M. Clark and Rowe (1971) incorporated O. exigua into the Key of Ophiuroidea in shallow water Indo-West Pacific, but did not list $O$. marenzelleri therein. According to A.M. Clark (1965) "Duncan's figures of the syntype of Ophiothrix koreana were not very good" and "the large syntype, has about 30 stumps on each radial shields". Her photograph of one of the syntypes of $O$. koreana (A.M. Clark 1965, pl. I, fig. 4) is very close to O. exigua.

\section{Ophiothrix koreana Duncan}

(Jap. name: Toge-kumohitode)

Ophiothrix koreana Duncan, 1879, p. 473, pl. XI, figs. 28-32, Lyman, 1882, p. 226; H.L. Clark, 1911, p. 257, figs. 127 \& 128; Matsumoto, 1917, p. 220; Murakami, 1942, p. 20: 1943c, p. 232: 1944b, p. 267: 1963, p. 176; A.M. Clark, 1965, p. 61 pl. 1, figs. $3 \& 4 .:$ 1966, p. 647: Irimura, 1979, p. 3. Ophiothrix abstineus Koehler, 1930, p. 153, pl. XX, figs. 5 \& 8.

Material examined: off Minabe, by fishing net, 100-200 m deep, March 12, 1944 (Oph. 52); off Minabe, by fishing net, ca. $150 \mathrm{~m}$ deep, Dec. 28, 1970 (Oph. 94). Other record: Shirahama (Murakami 1963).

Distribution: Japanese coasts from Hakodate Bay to Kagoshima Bay, Korea Strait, Korea, East China Sea, Banda Sea, Amboina, Kei Is., Siam Bay. 
Remarks: As A.M. Clark (1965) claimed, "Duncan's figures of the syntypes of Ophiothrix koreana were not very good", "the largest syntype has about 30 stumps on each radial shield" and "this smallest syntype, superficially resembles H.L. Clarks's figure of Ophiothrix hylodes (1911), which Matsumoto and subsequently, Clark himself referred to the synonymy of Ophiothrix marenzelleri Kochler". Then she deduced "so close are the types of $O$. koreana to the form generally accepted as $O$. marenzelleri that I think the later name might well be considered a synonym". I also take a view that, $O$. marenzelleri and $O$. hylodes are both junior synonyms of $O$. exigue Koehler. $O$. koreana sensu Duncan may also by synonymized with $O$. exigua, although the name "koreana" has been applied for a different species by many authors. A.M. Clark and Rowe (1971) did not list $O$. koreana in their monograph.

And also A.M. Clark (1965) described, "Judging from the variation of $O p h$ iothrix fragilis in the north Atlantic, it is quite possible that the Japanese specimens hitherto designated as koreana, marenzelleri, hylodes and possibly even eusteria H.L. Clark, (1911), all represent a single very variable species". But I think that the character of radial shields whether carrying many armaments or being bare is important diagnosis for species Ophiothrix. Therefore, specimens identified to be O. "koreana" by Matsumoto (1917) differs from O. exigua. Based on A.M. Clark and Rowe's key (1971), the so-called "koreana" will be led to O. abstineus Koahler (1930), but Duncan's name has been retained in this paper.

Oph. 94 was found clinched to Calicogorgia granulosa. Color: very variable.

\section{Ophiothrix ciliaris (Lamarck)}

(Jap. name nov.: Higetoge-kumohitode)

Ophiura ciliaris Lamarck, 1816, p. 545.

Ophiothrix ciliaris Muller \& Troschel, 1842, p. 114; Lyman, 1874, pl. IV, figs. 29-32: 1882, p. 220; Koehler, 1904, p. 100 figs. 74 \& 75; H.L. Clark, 1915, p. 280; A.M. Clark \& Rowe, 1971, p. 109. Gulle \& Jangoux, 1978, p. 61 .

Ophiothrix carinata Martens, 1870, p. 255; Brock, 1888, p. 537; Koehler, 1904b, p. 90, figs. 55-59.

Ophiothrix stelligera Lyman, 1874, p. 237, pl. III, figs. 15-20: 1882, p. 220; Marktanner-Turneretscher, 1887, p. 310; Brock, 1888, p. 513; Döderlein, 1896, p. 294; Koehler, 1898, p. 100; Koehler, 1905, p. 87: 1907, p. 253; McIntosh, 1910, p. 162; H.L. Clark, 1914, p. 153: 1915, p. 279: 1921, p. 114, pl. 16, fig. 8 ; Koehler, 1922, p. 267, pl. 53, figs. 1-5, pl. 54, figs. 1-6, pl. 55, figs. 1-4, pl. 56, figs. 4-7, pl. 102, figs. $2 \& 3$ (par); Mortensen, 1934, p. 4; H.L. Clark, 1938, p. 273: 1946, p. 216.

Ophiothrix melanogramma Bell, 1884, p. 145.

Ophiothrix stabilis Koehler, 1904, p. 84, figs. 46 49; Matsumoto, 1917, p. 224; Murakami, 1944, p. 268.

Material examined: Ezura, littoral zone, under boulder, June 27, 1967 (Oph. 108). Distribution: Off Kobe, Misaki, Japan; Bengal Bay; West Pacific.

Remarks: A.M. Clark and Rowe (1971) made O. stelligera, O. melanogramma, $O$. carinata synonym of $O$. ciliata But I think $O$. stabilis Koehler is a junior synonym of $O$. cilialis too. Koehler (1904b) had recorded $O$. stabilis from Japan, and Matsumoto (1917) included it in the keys to Japanese species of genus Ophiothrix. 
But Koehler's description of $O$. stabilis is almost coincident to the characters of O. cilialis. Matsumoto (1917) emphasized in his keys that disk of O. stabilis is closely beset with stellate tubercles and thorny spines. Koehler's comment (1904), "bàtonnets, portant à leur extrémite une couronne de spinules courtes et coniques". This variability may be within an infraspecific polymorphism in dorsal armature of $O$. cilialis. For example, the specimens in Koehler (1922, pl. 54, figs. 1-3) are covered only with stellate tubercles. His comment, "piquants á la base du bras sont un peu elargis ver l'extremité"' is also within a polymorphic variation of arm spines. For example, pl. 55, figs. 1 and 3 in Koehler's (1922) seem to me that the edge of arm spines are a little widened, analogus phenomenon observed on $O$. exigua in the Japanese waters.

But I think that the character of disk armature whether radial shield being covered or naked is an important diagnosis of species within Ophiothrix, so that Ophiothrix eusteira H.L. Clark (1911) is valid although it was overlooked by A.M. Clark \& Rowe (1971). Part of the specimens which Koehler (1922) identified to be $O$. stelligela (pl. 54, figs. 1 \& 2, pl. 55, figs. $3 \& 4$ ) may belong to 0 . eusteira.

The dorsal disk of Oph. 108 (measuriug disk diameter $9 \mathrm{~mm}$ ) is covered by minute thorny tubercles which closely resemble to Koehler (1904)'s fig. 49. Color: yellowish green dorsally, a wider median dark line running along each arm bases, but they resolves itself distally into three or four lines.

\section{Ophiothrix marginata Koehler}

(Jap. name nov.: Uratoge-kumohitode)

(Fig. 4)

Ophiothrix marginata Kohler, 1905, p. 79, pl. VIII, figs. 7-9; A.M. Clark \& Rowe, 1971, p. 138.

Material examined: Off Sakai, by fishing net, ca. $100 \mathrm{~m}$ deep, March 22, 1975 (Oph. 109).

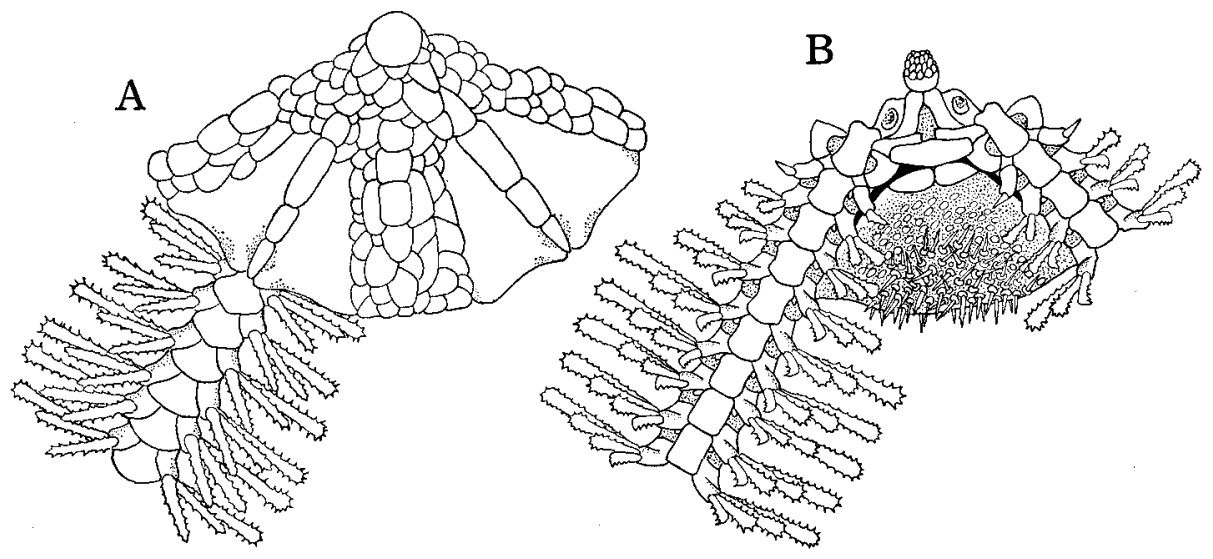

Fig. 4. Ophiothrix marginata. A: disk, dorsal view; B: disk, ventral view. 
Locality hitherto recorded: Aru Islands, near New Guinea.

Remarks: The present specimen measuring disk diameter $7 \mathrm{~mm}$, arm length ca. $50 \mathrm{~mm}$, larger than Koehler's holotype, a little differed from original description and figures that, in having an apparant central plate, carrying any granules, stumps, or spines on dorsal disk.; almost rectangular oral shields which are very wider than long with round corners. First ventral arm plates are very long, about twice longer than wide, following several basal ones being longer than wide and with the distal edge convex. Therefore, in A.M. Clark \& Rowe's key (1971) the position of O. marginata could be changed to 132 group instead of $132^{\prime}$ group.

\section{Ophiothrix (Acanthophiothrix) purpurea Martens}

(Jap. name nov.: Aka-toge-kumohitode)

Ophiothrix purpurea Martens, 1867, p. 346; Döderlein, 1896, p. 20, pl. XIV, fig. 12, pl. XVII, figs. 23 \& 23a; Koehler, 1898, p. 327: 1905, p. 102: 1922, p. 261, pl. 58, figs. 3 \& 4, pl. 101, fig. 6; H.L. Clark, 1915, p. 277.

Ophiothrix lepidus Loriol, 1893a, p. 45. pl. XXV, fig. 1.

Ophiothrix fallax Loriol, 1893a, p. 47, pl. XXV, fig. 2.

Ophiothrix lorioli Döderlein, 1896, p. 297, pl. XIV, figs. 13a \& 13b, pl. XVII, figs. 24 \& $24 a$.

Placophiothrix purpurea H.L. Clark, 1939, p. 86; A.M. Clark \& Spencer Davis, 1966, p. 599.

Ophiothrix (Acanthophiothrix) purpurea A.M. Clark, 1967c, p. 648; A.M. Clark \& Rowe, 1971, p. 112, figs. 35d \& 36, pl. 15, figs. 4-11; Devaney, 1974, p. 141; Gherbonnier \& Guiller, 1978, p. 148, pl. IV, figs. 5 \& 6; Guille \& Jangoux, 1978, p. 62; Sloan, A.M. Clark \& Tayler, 1979, p. 103.

Material examined: Off Minabe, by fishing net, ca. $50 \mathrm{~m}$ deep, Feb. 20, 1976 (Oph. 91).

Distribution: Indo-West Pacific area.

Remarks: This is the first record of the species from the Japanese waters. Color: brownish red, a dark longitudinal line through on the dorsal arms.

\section{Ophiothrix (Keystonea) nereidina (Lamarck)}

(Jap. name: Aosuzi-kumohitode)

Ophiura nereidina Lamarck, 1816, p. 544.

Ophiothrix nereidina Müller \& Troschel, 1842, p. 115; Lyman, 1882, p. 221; Studer, 1882, p. 26; Döderlein, 1888, p. 832, pl.XXXI I, figs. 5a-5c; Koehler, 1898, p. 97. 1907, p. 334; Matsumoto, 1917 , p. 224, fig. 61 .

Ophiothrix cataphracta Martens, 1870, p. 259; Lyman, 1882, p. 227.

Ophiotrichoides nereidina H.L. Clark, p. 306; Murakami, 1944b, p. 268: 1963, p. 176.

Ophiothrix (Keystonea) nereidina A.M. Glark, 1966, p. 648: 1971, p. 107.

Material examined: Tanabe Bay, Aug. 9, 1928 (Oph. 4); Seto, littoral zone, Sep. 1, 1928 (Oph. 6); near S.M.B.L., littoral zone Apr. 4, 1928 (Oph. 48). Other record: Seto (Murakami 1963).

Distribution: From Sagami Bay to Indo-West Pacific area.

Remarks: Some specimens were found clinched to gorgonians or the feather star, Tropiometra afra macrodiscus. 


\section{Macrophiothrix longipeda (Lamarck)}

(Jap. name: Udenaga-kumohitode)

Ophiura longipeda Lamarck, 1816, p. 544.

Ophiothrix longipeda Muller \& Troschel, 1842, p. 113; Lyman, 1882, p. 220, pl. XLVII, fig. 4; Döderlein, 1899, p. 293, pi. XIV, figs. 6a-6c; Koeeler, 1905, p. 92: 1907, p. 334; H.L. Clark, 1911 , p. 263; Matsumoto, 1917, p. 227, fig. 65; Koehler, 1922, p. 235, pl. 31, figs. 3 \& 4, pl. 35, figs. 9 \& 10; Balinsky, 1957, p. 17.

Ophiothrix microplax Bell, 1884c, p. 143.

Ophicthrix punctolimbata von Martens, 1870, p. 257, (non Loriol 1893a)

Macrophiothrix longipoda H.L. Clark, 1938, p. 288; Murakami, 1943b, p. 209; H.L. Clark, 1946, p. 221; A.M. Clark, 1968, p. 300; Irimura, 1969, p. 44; A.M. Clark \& Rowe, 1971, p. 114, fig. 37-1; Devaney, 1974, p. 140; A.M. Clark \& Courtman-Stock, 1976, pp. 112 \& 139; Cherbonnier \& Guille, 1978, p. 153, pl. IV, figs. 3 \& 4, figs. 61-28 \& 29; Saloan, A.M. Clark \& Taylor, 1979, p. 102.

Material examined: Near S.M.B.L., under boulder in littoral zone, Jan. 15, 1955 (Oph. 57); near Tohshima, $2 \mathrm{~m}$ deep, under boulder, Aug. 30, 1979 (Oph. 103); Tanjiri, $2 \mathrm{~m}$ deep, under boulder, Nov. 16, 1979 (Oph. 105); Sakata, $1.5 \mathrm{~m}$ deep, under boulder, Nov. 16, 1978 (Oph. 106).

Distribution: From Sagami Bay to Indo-West Pacific area.

Remarks: This species is very abundant in the rocky littoral zone of Tanabe Bay. Oph. 106 is covered with many thorny spinelets on the dorsal arm plates. Color in alcohol: purplish blue, dark annulations on the dorsal arms. Usually dark spots on the radial shields and on the dorsal arm plates, but a few specimens have not them.

\section{Ophiothela danae Verrill}

(Jap. name: Nishiki-kumohitode)

Ophisthela danae Verrill, 1869, p. 391 ; Lyman, 1882, p. 230; Döderiein, 1897, pl. XVII, figs. 25-25b; Koehler, 1898, p. 89: 1905, p. 117: 1907, p. 253; H.L. Clark, p. 284; Matsumoto, 1917, p. 230, fig. 67; Koehler, 1922, p. 297, pi. 59, figs. 1-3: 1930, p. 198; Mortensen, 1940, p. 68; Murakami, 1942, p. 20: 1944a, p. 269; A.M. Clark \& Spencer Davies, 1966, p. 599; Irimura, 1969, p. 44; A.M. Clark \& Rowe, 1971, p. 116; A.M. Clark \& Courtman-Stock, 1976, p. 114; Cherbonnier \& Guiler, 1978, p. 158, pl. VIII, figs. 3 \& 4.

Ophiothela isidicula Lutken, 1872, p. 92, pls. 1 \& 2, figs. 4a-g.; Loriol, 1893a, p. 52.

Ophiothela verrilli Duncan, 1879, p. 477, pl. 11, fig. 33.

Ophiothela dividua Martens, 1879, p. 127; Ballnsky, 1957, p. 22.

Ophiothela danae involta Koehler, 1898, p. 88.

Ophiothela coerulea H.L. Clark, 1915a, p. 283, pl. 14, fig. 1 .

Ophiothela hadra H.L. Clark, 1915a, p. 284, pl. 14, fig. 2.

Material examined: Tohshima, Aug. 10, 1953 (Oph. 54); off Minabe, by fishing net, Feb. 13, 1969 (Oph. 89).

Distribution: From Sagami Bay to the Indo-West Pacific area.

Remarks: Oph. 54 was found clinched to Anthoplexaura sp. and Oph. 89 to Dendronephthya sp. 


\section{Ophiogymna elegans Ljungman}

(Jap. name: Momoiro-udenaga-kumohitode)

Ophiogymna elegans Ljungman, 1866, p. 136; Studer, 1885, p. 27; H.L. Clark, p. 286, pl. XII, figs. 7 \& 8; Koeher, 1922, p. 281, pl. 43, figs. 3-8: 1930, p. 188; H.L. Clark, 1938, p. 320; Mortensen, 1940 , p. 68; Murakami, 1942, p. 20: 1944b, p. 268; Irimura, 1969, p. 44; A.M. Clark \& Rowe, 1971, p. 117.

Ophiocampsis inermis Koehler, 1905, p. 115, pl. XIII, fig. 7: 1910. p. 295.

Material examined: Tohshima, low tide level, Apr. 27, 1959 (Oph. 61); Tohshima, low tide level, Apr. 27, 1959 (Oph. 62); Tohshima, low tide level, March 9, 1967 (Oph. 70).

Distribution: From west part of Sagami Bay to the Indo-West Pacific area.

Remarks: Oph. 61 was found clinched to Dendronephthya nipponica, Oph. 62 to Dendronephthya gigantia, and Oph. 65 and 70 were found clinged to Dendronephthya sp. This species has been found clinched limitedly to alcyonaceans. Color: disk rosy red or blue, arms rosy red or blue with white annulations.

\section{Ophiogymna fulgens (Koehler)}

(Figs. 5, $6 \& 7$ )

(Jap. name: Togetosaka-kumohitode)

Ophiothrix falgens Koehler, 1905, p. 107, pl. 10, figs. 3-6; H.L. Clark, 1915, p. 280.

Ophiothrix macrobrachia H.L. Clark, 1911, p. 267, fig. 133.

Ophiegymna fulgens KoEHLer, 1922, p. 288, pl. 43, figs. 9 \& 10, pl. 44, fig. 8, pl. 103, fig. 8: 1930, p. 189; Mortensen, 1933a, p. 338, pl. 19, fig. 25; A.M. Clark \& Courtman-Stock, 1976, p. 140.

Placophiothrix phrixa H.L. Clark, 1939, p. 88, figs. 39 \& 40.

Material examined: Seto, low tide level, July 29, 1959 (Oph. 60).

Distribution: West of Sagami Bay, Japan; Korea Strait, East China Sea, Philippine, Indonesia.

Remarks: H.L. Clark (1911) recorded Ophiothrix macrobrachia from several Albatross stations around Japan, namely in the Korea Straits and the East China Sea, but he did not find Ophiogymna fulgens in these areas. On the other hand, Koehler (1922), who dealt with the Albatross specimens from the Philippines and the waters around Japan, reported many specimens of Ophiogymna fulgens from several stations. Some of these stations are near those where H.L. Clark could find Ophiothrix macrobrachia but no specimen of Ophiogymna fulgens.

The descriptions and figure of Ophiothrix macrobrachia given by H.L. Clark (1911) seem to warrant most characters of the genus Ophiogymna, namely the disk is covered with a thick naked skin through which only the distal ends of the radial shields are projected. Thus, A.M. Clark (1966) briefly pointed out that Ophiothrix macrobrachia might belong to the genus Ophiogymna.

According to Koehler's emendation (1922) of the diagnosis of the genus Ophio- 
gymna, the ophiurans with the dorsal disk covered wish the integument, which was called by H.L. Clark (1911) "thick skin", should belong to the genus Ophiogymna.

Then the close examinations of the holotype of Ophiothrix macrobrachia and Koehler's Ophiogymna fulgens lent out to me from U.S. National Museum through the courtesy of Dr. D. Pawson, made it clear that both species are identical. In the holotype of Ophiothrix macrobrachia, the arms are very long, twisting and rolling in every plane and the dorsal arm plates are covered with a thin tegument and occasionally divided into two or three pieces at the arm base; the latter is also one of the important characters of the genus Ophiogymna. Further, there are long, slender spines on the disk and the distal border of the dorsal arm plates are strongly convex (Fig. 5, A.) as in Ophiogymna. For these reasons I believe that Ophiothrix macrobrachia is a junior synonym of Ophiogymna fulgens.

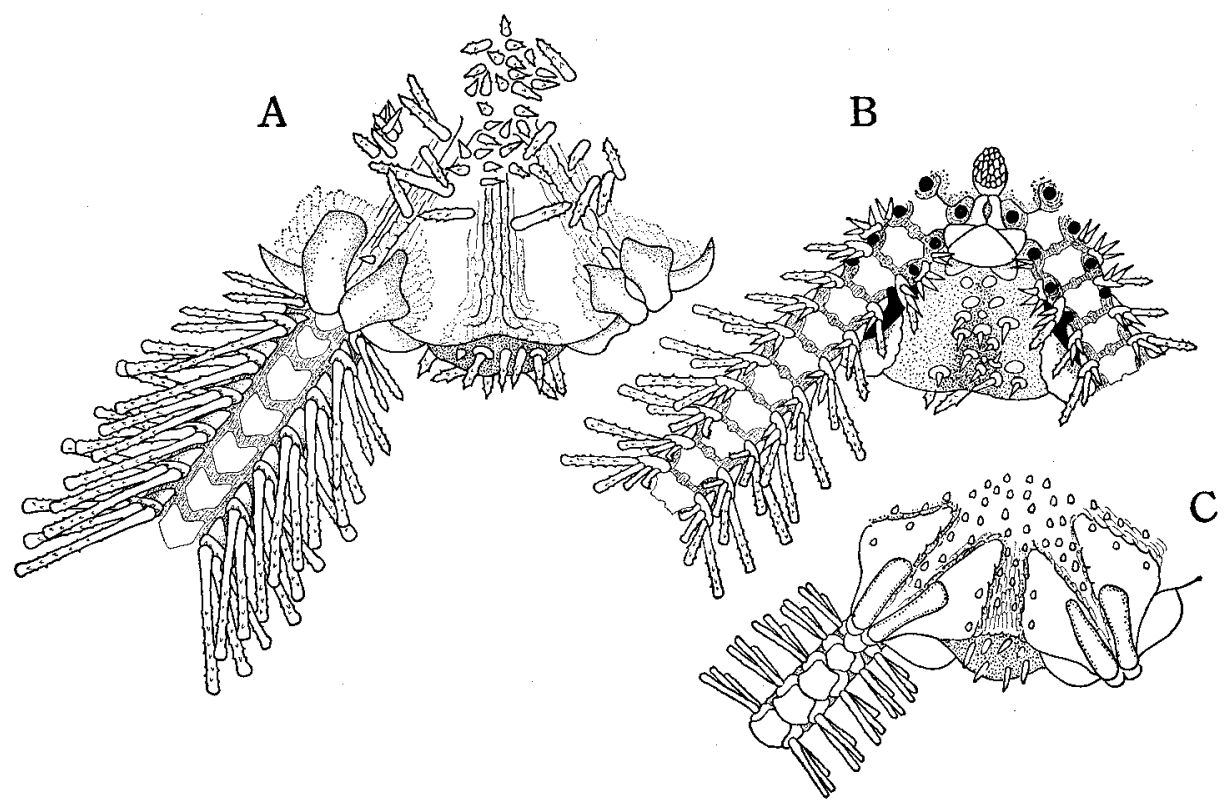

Fig. 5. Ophiogymna fulgens. A: dorsal view of the specimen U.S.N.M. 26713 (holotype of Ophiothrix macrobrachia); B: ventral view of the same specimen; $\mathrm{C}$ : dorsal view of the specimen Oph. 60 .

Closer reexamination of the Albatross specimens revealed that H.L. Clark made some small errors or oversight in his description of Ophiothrix macrobrachia. He described, "Disk covered with a thick skin containing scales", but in reality the thick skin does not contain any scales; instead, there are merely scale-like folds. Further he he stated, "Interbrachial space below quite naked, the thin skin with only a few scattered minute spinelet", but actually there are many small lumps of the thick skin in the interbrachial space, and short and acute spines are distributed among them.

Arms are very long and strongly twisting in the holotype. The dorsal arm plates are nearly all undivided, though the basal first and second plates of an arm are longitudinally split into two pieces. The plates of another arm base are deformed to 
small irregular pieces. The dorsal arm plates are devoid of small granules. Arm spines are not "smooth" but rugous; there are not "eight" but seven spines at the arm base and the undermost one is changed to a hooklet. No tentacle scale is found.

This holotype resembles closely a specimen of Ophiogymna fulgens reported by Koehler (1922, pl. 42, fig. 8) from the Albatross station 5545. The specimen Cat. No. 41079, U.S.N.M. (Albatross station 5393), which was identified by Koehler (1922) as Ophiogymna fulgens, has the disk diameter of $9 \mathrm{~mm}$ and the arm length estimated to be $50 \mathrm{~mm}$. In this specimen, the thick skin on the dorsal disk assumes an aggregation of small scale-like lumps, among which long needlelike spines are distributed. Radial shields are almost completely exposed, their interradial edge being covered with thin scales. In the infrabrachial space of the ventral disk, there are needle-like spines on small lumps or directly appearing from the surface of the thin skin.

Each dorsal arm plate may frequently be divided into two to five parts, but never be granulated. The ventral arm plates are trapezoid in outline, with corners rounded, the distal margin with a large notch, and proximal margin slightly convex. There are eight arm spines, the undermost one of them is changed to a hooklet at the arm base; in the middle of arm, however, the spines decrease to six or seven, of which two or three, or less, are furnished with the hook-like denticulation. A minute tentacle scale is recognized at the middle of arms. (Fig. 7)

The specimen Cat. No. 41090, U.S.N.M. (Albatross station 4948) was also identified by Koehler (1922) with Ophiogynma fulgens. This specimen is smaller, with the disk diameter $5 \mathrm{~mm}$ and the arm length ca. $25 \mathrm{~mm}$. The dorsal disk is

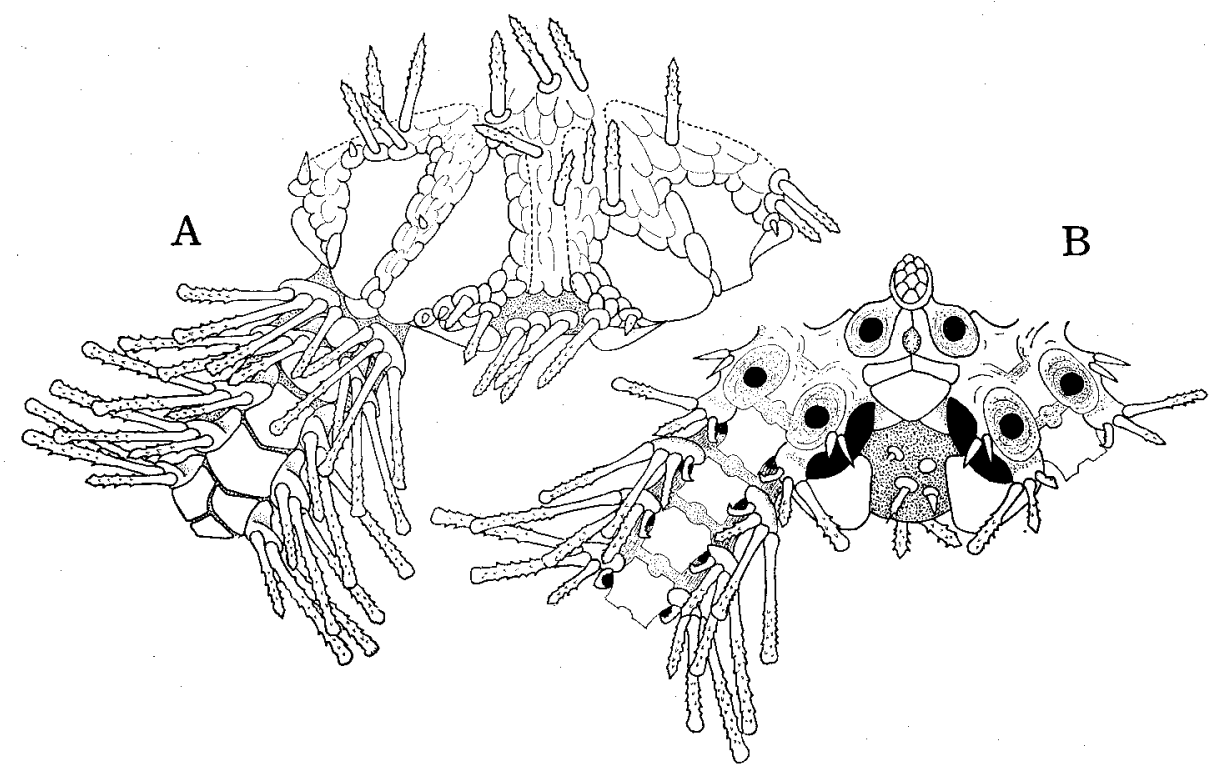

Fig. 6. Ophiogymna fulgens. A: the specimen U.S.N.M. 41090, dorsal view; B: ventral view of the same specimen. 


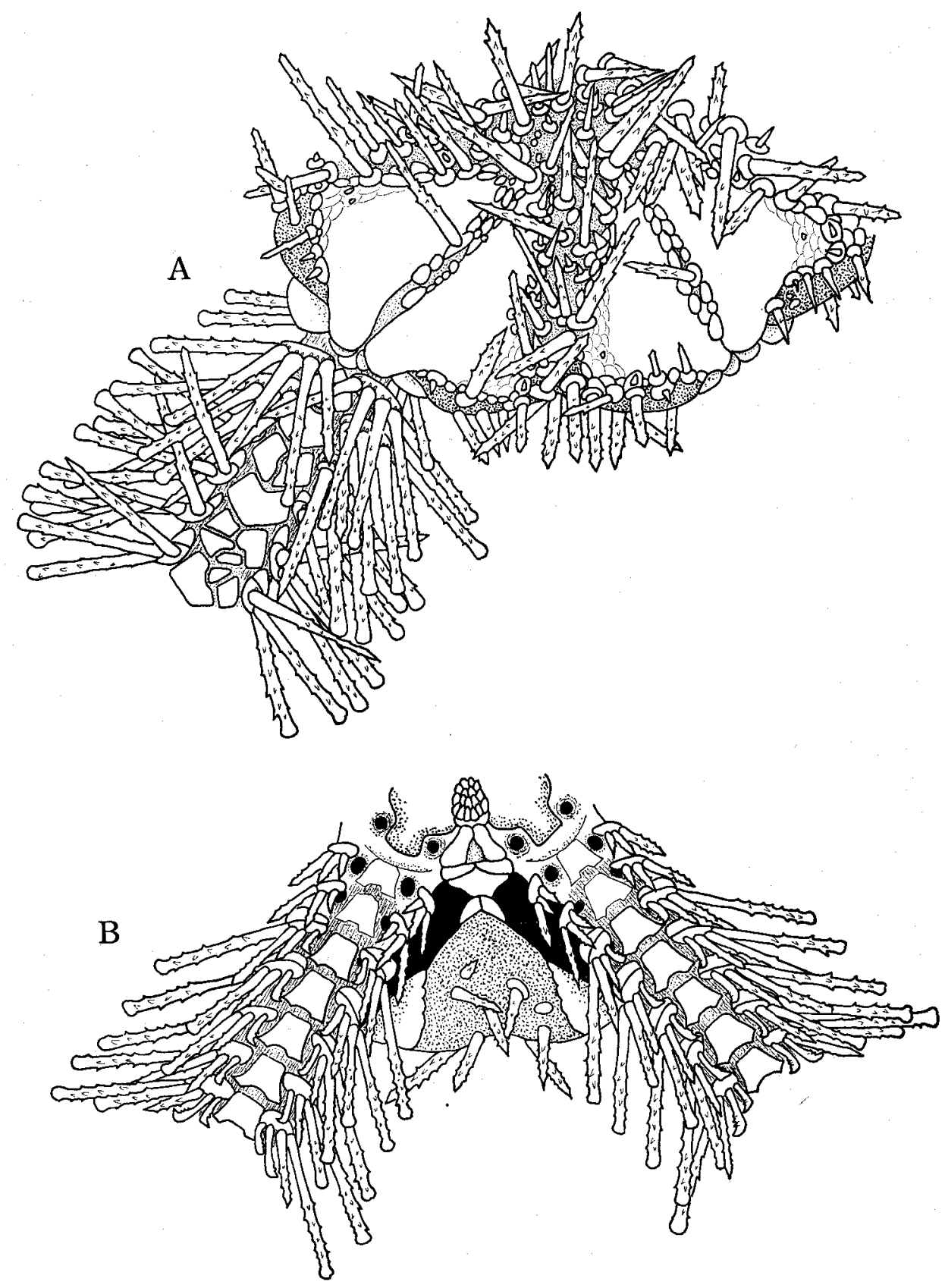

Fig. 7. Ophiogymna fulgens. A: the specimen U.S.N.M. 41079, dorsal view; B: ventral view of the same specimen. 
covered with the thick skin, on which are distributed many scale-like folds that may be transformed into small scale-like lumps towards the periphery. Several long needle-like spines are born by the side of lumps or appear directly spearing through the thick skin. Radial shields are exposed partly, one third to half of their length, and the exposed part is very irregular in outline. The interbrachial space of the ventral disk is covered with a thin skin, on which a few lumps of the thick skin are scattered; some of them bear a short spine, while the others have none. Oral shields are more or less rhombic, wider than long, and with round corners; the proximal corner is obtuser than the distal one.

The dorsal arm plates are occasionally split into two or three pieces and never granulated. The ventral arm plates are hexagonal, their proximal and distal margins have respectively a round median notch. Arm spines are eight in the basal part of arms, and the undermost spine is transformed into a hooklet. Tentacle scales are never found on any arm (Fig. 6).

The feature of the above-mentioned specimen seems to show an intermediate state between the holotype of Ophiothrix macrobrachia from the Albatross station 4875, (Cat. No. 25712 U.S.N.M.) and the specimen of Ophiogymna fulgens from the Albatross station 5393 (Cat. No. 41079 U.S.N.M.).

Of the specimens from Tanabe Bay, Oph. 60 SMBL. has a disk diameter of $6 \mathrm{~mm}$ and the arm length of approximately $60 \mathrm{~mm}$. The disk is covered with a thick skin, but there are no small nodules but many fine scale-like lumps in the interradial area. Disk spines are short, conic, though transformed into long spines in the distal area. Radial shields are narrow, elongate rectangular and with rounded corners; and they are exposed only at their distal part. These characters of the disk resemble closely those of the specimen of Ophiogymna fulgens Cat. No. 41088, 41096, U.S.N.M., Albatross station 4948 (Koehler 1922, pl. 42, fig. 6). Dorsal arm plates are not divided; the first and second ones are smaller than the others. There are five arm spines (Fig. 5, C).

Ecological notes: This species is often collected in the infralittoral zone on the Pacific coast of Japan, mostly clinched to alcyonaceans of the genus Dendronephthya. Probably for this behavior, the arms of this species are very long, up to fifteen times as long as the disk diameter, and strongly convolute. The specimen Oph. 60 treated in the present studies was found clinched to Dendronephthya gigantia. Color: rosy red on the dorsal disk; rosy red and white band are alternating to form annulations on the dorsal arm.

\section{Ophiomaza cacaotica Lyman}

(Jap. name: Komachi-kumohitode)

Obhiomaza cacaotica Lyman, 1871, p. 9, pl. I fig. 15; Döderlein, 1896, p. 198, pl. XVII, figs. 26 \& 26a; Koehler, 1898a, p. 85: 1905, p. 111; 1907, p. 339; H.L. Clark, 1915, p. 283; Koehler, 1922, p. 299: 1930, p. 193; Mortensen, 1940a, p. 68; Murakami, 1944b, p. 268; H.L. Clark, p. 234; A.M. Glark \& Rowe, 1971, p. 116, pl. 17, fig. 1; Cherbonnier \& Guille, 1978, p. 155, 
pl. VIII, figs. $1 \& 2$.

Ophiomaza cacantica pica Koehler, 1895, p. 405, pl. 9, fig. 8.

Ophiomaza kanekoi Matsumoto, 1917, p. 227, fig. 66; Murakami, 1944b, p. 269; Irimura, 1969, p. 44.

Material examined: Shiso-jima, low tide level, July 21, 1967 (Oph. 71).

Distribution: From Shimabara and Amakusa in Japan to the Indo-West Pacific area.

Remarks: Matsumoto (1917) described $O$. kanekoi on the holotype with a disk diameter of $15 \mathrm{~mm}$. The diagnosis of $O$. kanekoi given by him, such as the numerous disk scales, absence of a distinct central rosette of the primary plates, irregularly arranged marginal disk scales, narrower arms at the arm base. I think, the concave outer border of the ventral arm plates, six or seven arm spines on the basal arm, are all the characters of mature specimens of $O$. cacaotica. As Cherbonnier \& Guille (1978) placed $O$. kanekoi under $O$. cacaotica as a junior synonym, the holotype of the former is regarded as a fully matured specimen of the latter.

Family Ophiuridae Lyman, 1865

Subfamily Ophiurinae Lyman, 1865

36. Stegophiura sladeni (Duncan)

(Jap. name: Akahako-kumohitode)

Ophioglypha slareni Duncan, 1879, p. 458, pl. IX, figs. 9-11; Lyman, 1882, p. 77.

Stegophiura sladeni Matsumoto, 1915, p. 79: 1917, p. 259, fig. 72, pl. V, fig. 6; Koehler, 1922, p. 369, pl. LXXXIII, figs. 4-7, pl. 84, fig. 1; Murakami, 1963, p. 177; D'yakonov, 1949, p. 58, fig. 84.

Ophiura stiphra H.L. Clark, 1911, p. 83, fig. 25.

Record from the vicinity: Off Minabe (Murakami 1963)

Distribution: Japanese and Korean coasts, Japan Sea.

Remarks: Color: red dorsally, but creamy white ventrally.

\section{Stegophiura sterea (H. L. Clark)}

(Jap. name: Hako-kumohitode)

Ophioglypha sterea H.L. Clark, 1908, p. 293.

Ophiura sterea H.L. Clark, 1911, p. 75, fig. 22.

Stcgophiura sterea Matsumoto, 1917, p. 258, fig. 71; Murakami, 1942, p. 27; D'yakonov, 1949, p. 58: 1954, p. 95; Murakami, 1963, p. 177.

Material examined: Off Minabe, by fishing net, March 12, 1944 (Oph. 2). Other record: Off Minabe (Murakami 1963).

Remarks: Color: vermilion or red dorsally, but creamy white ventrally. 


\section{Ophiura kinbergi (Ljungman)}

(Jap. name: Kushinoha-kumohitode)

Ophioglypha kinbergi Ljungman, 1866, p. 166; Lyman, 1882, p. 38, pl. IV, fig. 70.

Ophiura kinbergi H.L. Clark, 1911, p. 37, fig. 9; Matsumoto, 1917, p. 271, fig. 73; H.L. Clark, 1921, p. 141; Koehler, 1922, p. 381; Matsumoto, 1941; p. 343, fig. 9; Murakami, 1942, p. 26: 1943c, p. 233: 1944b, p. 269; D'yakonov, 1954, p. 113; Murakami, 1963, p. 178; A.M. Clark \& Rowe, 1971, p. 128, fig. 46 b. pl. 22, figs. 5 \& 6; Devaney, 1974, p. 187; Guille \& Jangoux, 1978, p. 71 ; Irimura, 1979 , p. 4.

Ophioglypha sinensis Lyman, 1871, p. 12, pl. I, figs. 1 \& 2; Koehler, 1898, p. 60

Ophioglypha ferruginea Lyman, 1978, p. 68, pl. III, fig. 9.

Material examined: Near Tohshima, $28 \mathrm{~m}$ deep, by S.M. grab, May 16, 1978 (Oph. 101); off Tanabe Bay, $58 \mathrm{~m}$ deep, by S.M. grab, May 16, 1978.

Distribution: Mutsu Bay, Japan Sea, from Pacific coasts of Japan to Indo-West Pacific area.

Remarks: Color: very variable; dark brown, yellow; blue, or green.

\section{Aspidophiura forbesi (Duncan)}

(Jap. name: Usumurasaki-kumohitode)

Ophioglypha forbesi Duncan, 1879, p. 449, pl. IX, figs. 1-3; Lyman, 1882, p. 7; Koehler, 1905, p. 22. Ophiura glyptodisca H.L. Clark, 1911, p. 91, fig. 31.

Aspidophiura forbesi Matsumoto, 1917, p. 253; Guille \& Jangoux, 1978, p. 71, figs. 9a \& b.

Material examined: Off Setozaki, $47 \mathrm{~m}$ deep, sandy bottom, by dredge, Feb. 20, 1957.

Distribution: Off Boso Peninsula, Sagami Bay, Suruga Bay, Korea Strait, Indian Ocean, Malay Waters. Amboina Is.

Remarks: Color: faintly purplish or pinkish.

\section{Ophiomusium simplex Lyman}

Ophiomusium simplex Lyman, 1878, p. 115, pl. I, figs. 10 \& 11: 1882, p. 93, pl. I, figs. 7-9; H.L. Clark, 1911, p. 109; Matsumoto, 1917, p. 228; Murakami, 1963, p. 179.

Ophiomusium sanctum Kohler, 1904, p. 59, pl. XI, figs. 7-9.

Record in the vicinity: Off Minabe (Murakami 1963).

Distribution: East China Sea, Malay Waters, Amboina.

\section{Ophiomusium scalare Lyman}

(Jap. name: Taira-ishigaki-kumohitode)

Ophiomulum scarare Lyman, 1878, p. 117, pl. I, figs. 1-3: 1882, p. 95, pl. I, figs. 4-6; Koehler, 1896, p. 308, pl. VI, figs. 24 \& 25: 1899, p. 26, pl. II, figs. 12 \& 13. pl. III, fig. $21: 1904 a$, p. $65: 1906$, p. 6: 1907, p. 266; Matsumoto, 1917, p. 286, fig. 77. 
Material Examined: Off Minabe, ca. $100 \mathrm{~m}$ deep, by fishing net, March 10, 1944 (Oph. 5); off Minabe, by fishing net, Feb. 12, 1952 (Oph. 24); Tanabe Bay, by dredge, June 28, 1957 (Oph. 78).

Distribution: Cosmopolitan in the world deep seas. In the Japanese waters, Uraga Channel, Sagami Bay, Suruga Bay, off Miyake Is., off Koshiki Is.

Remarks: Color: generally red, but the dorsal side of the arm with one or two lighter joints at irregular intervals.

\section{Ophiomusium trychnum H. L. Clark}

(Jap. name: Ishigaki-kumohitode)

Ophiomusium trychnum H.L. Glark, 1911, p. 109, fig. 40; Matsumoto, 1917, p. 290, fig. 78.

Material examined: Off Minabe, by fishing net, March, 1944 (Oph. 1). Other records from Tanabe Bay were noted by Murakami (1963).

Remarks: Color: the dorsal disk is red and with white patches; the dorsal side of arms is red, with darker and lighter stripes.

\section{Ophioplocus japonicus H. L. Clark}

(Jap. name: Nihon-kumohitode)

Ophioplocus japonicus H.L. Clark, 1911, p. 30, fig. 5; Matsumoto, 1917, p. 302, fig. 83: Murakami, 1942, p. 31 : 1944b, p. 270: 1963, p. 179; Irimura, 1979, p. 4.

Material examined: Seto, under boulder at low tide level, Apr. 4, 1925 (Oph. 37); Seto, ca $3 \mathrm{~m}$ deep, under boulder, Aug. 30, 1979 (Oph. 102).

Distribution: West of Cape Inubo on the Pacific coast of Japan, Japan Sea.

Remarks: Color: deep olive-green or chocolate, arms irregularly annulated with dark and light bands.

\section{Ophiolepis utinomii Irimura}

(Jap. name: Utinomi-kumohitode)

Ophiolepis utinomii Irimura, 1967, p. 353, fig. 1 .

Record in Tanabe Bay: Hatake-jima, under boulder at low tide level, (Irimura 1967). Remarks: Color: brown.

\section{Ophiozonella longispina (H. L. Clark)}

(Jap. name: Mozaiku-kumohitode)

Ophiozona longispina H.L. Clark, 1908, p. 290: 1911, p. 33.

Ophiozonella longispina Matumoto, 1915, p. 82; H.L. Clark, 1915, p. 338, pl. XX, figs. 5 \& 6, Matsumoto, 1917, p. 297, fig. 80, pl. V, fig. 9; Murakami, 1942, p. 29: 1963, p. 179. 
Material examined: Off Minabe, by fishing net, Jan. 16, 1954 (Oph. 59). Other record: Off Minabe (Murakami 1963).

Distribution: Off Boso Peninsula, Uraga Channel, Sagami Bay, Suruga Bay, off Kii, off Tosa.

Remarks: Color: rosy red.

\section{Ophiozonella projecta (Koehler)}

(Jap. name: Chibi-mozaiku-kumohitode)

(Fig. 8)

Ophiozona projecta Koehler, 1905, p. 19, pl. I, figs. 16-18; H.L. Clark, 1911, p. 36.

Ophiozonella projecta Matsumoto, 1917, p. 295, fig. 79.

Material examined: Off Minabe, by fishing net, Dec. 28, 1970 (Oph. 104).

Distribution: Sagami Bay, off Niijima, East China Sea, Indonesia.

Remarks: The examined specimen is $5 \mathrm{~mm}$ in disk diameter. The disk is flat and pentagonal in outline. Large plates are more or less convex and thicker at the outer edge and carrying one or two small tubercles, on the surface as seen in the description and figure given by Koehler, though they are more in number than those seen in the figures given by Koehler and Matsumoto. Small plates are not arranged to surround larger ones. Arms are slender, dorsal arm plates are triangular, arm spines are short, blunt and three at the arm base. Color: reddish purple dorsally.

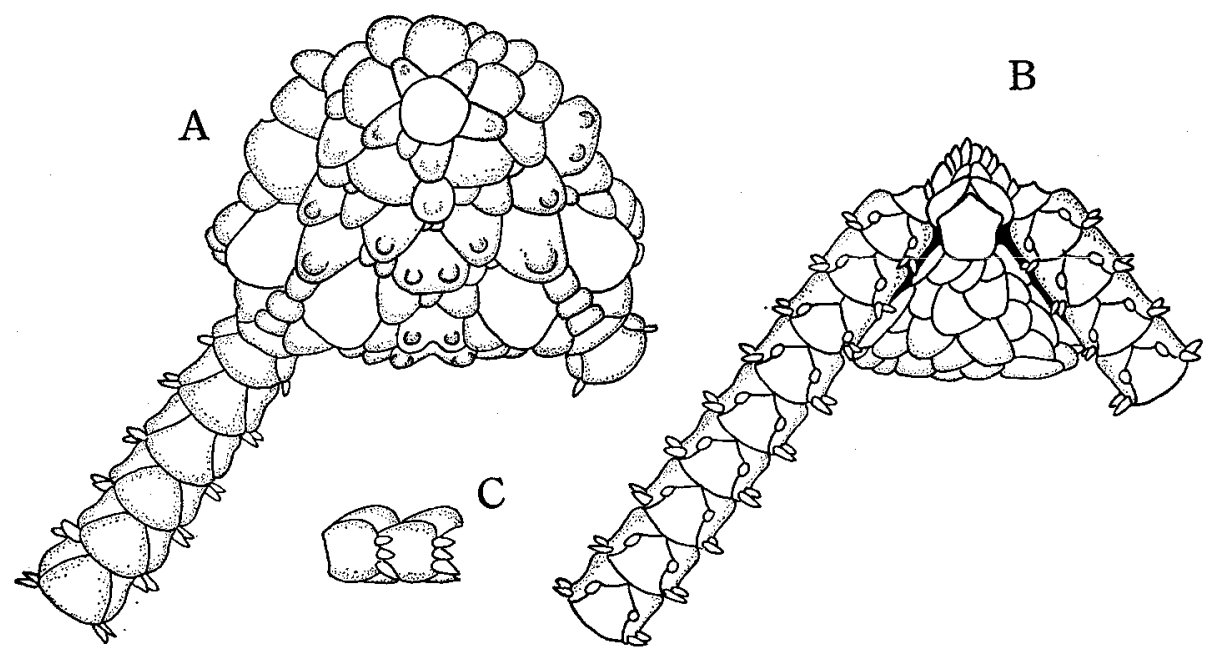

Fig. 8. Ophiozonella projecta. A: dorsal view; B: ventral view; C: side view of arm.

\section{Ophiozonella oedilepis (Murakami)}

(Jap. name: Kuriishi-kumohitode)

(Fig. 9) 
Ophiozona oedilepis Murakami, 1942, p. 29. fig. 11.

Material examined: Off Minabe, by fishing net, March 22, 1971 (Oph. 82).

Distribution: Sagami Bay.

Remarks: 'This species has been known only by Murakami's description (1942) of the holotype from Sagami Bay with a disk diameter of $4 \mathrm{~mm}$. The examined specimen Oph. 82 is a mature individual with a disk diameter of $6 \mathrm{~mm}$. The disk is slightly convex; the central plate is large, but other primary plates are partly missing and arranged irregularly. The large and small plates are very thick and the latter never surround the former.

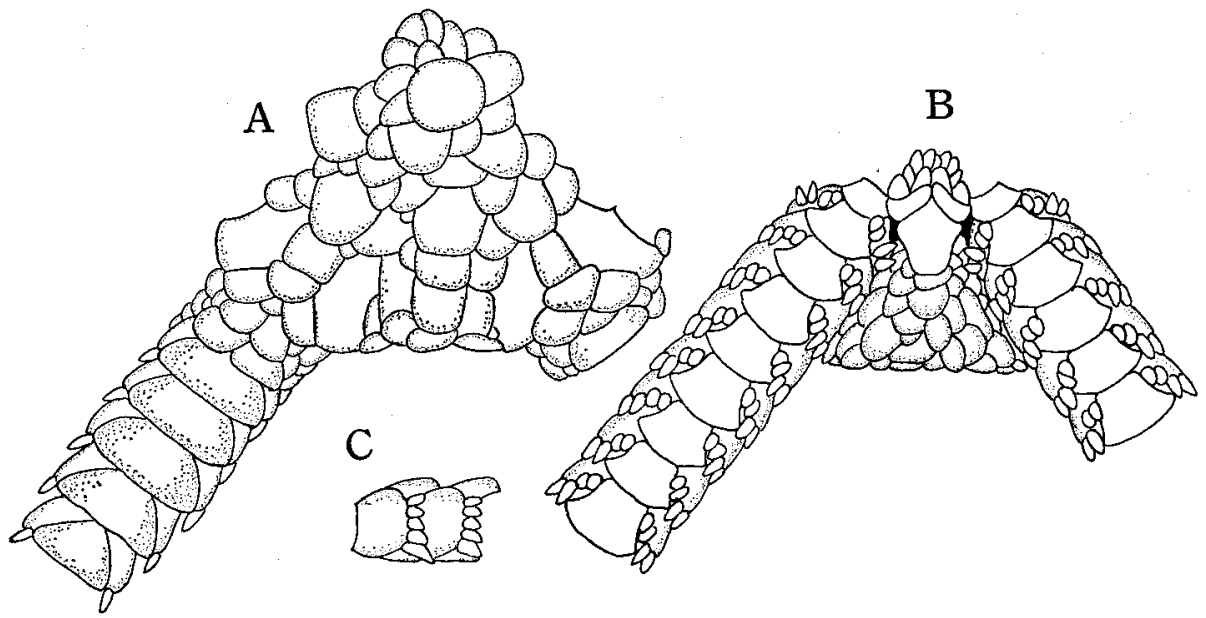

Fig. 9. Ophiozonella oedilepis. A: dorsal view; B: ventral view; G: side view of arm.

Arms are stout, broader than thick, and tapering gradually. The first dorsal plates are very small, triangular; the second and third plates are occasionally split longitudinally into two pieces. Following plates are rectangular, twice as wide as long, and transformed into triangular pieces in the middle part of the arm. Arm spines are five, the undermost one is the largest. Color: the dorsal disk and arms are grayish black, but the outer edge of large disk plates is white and the ventral side of the body is lighter.

Murakami (1942) placed this species in the genus Ophiozona; but unlike Ophiozona impressa and $O$. pacifica, the large disk plates are not surrounded by a belt of small plates in this species. This species is closely allied to Ophiozonella projecta, which was transferred by Matsumoto (1917) to genus Ophiozonella from genus Ophiozona. Therefore, similarly the transfer of Ophiozona oedilepis to the genus Ophiozonella is proposed here.

Family Ophiodermatidae Ljungman, 1867

48. Ophiarachnella gorgonia (Müller \& Troschel)

(Jap. name: Tohme-kumohitode) 
Ophiarachna gorgonia Müller \& Troschel, 1842, p. 105; Lyman, 1865, p. 39.

Pectinura gorgonia Lütken, 1869, p. 15; Lyman, 1882, p. 15; Koehler, 1905, p. 8; H.L. Glark, 1908, p. 289.

Pectinura marmorata Lyman, 1874, p. 222, pl. V, figs. 1-7.

Pectinura intermedia Bell, 1888, p. 386.

Pectinura ramsavi Bell, 1888, p. 386.

Pectinura stearnsii Ives, 1891, p. 212, pl. XI, figs. 1-5.

Pectinura venusta Loriol, 1894, p. 16, pl. XXIII, figs. 3-3h.

Ophiarachnella gorgonia H.L. Clark, 1909, p. 117; Matsumoto, 1917, p. 323; Murakami, 1942, p. 33: 1943a, p. 187: 1943b, p. 214: 1944b, p. 272: 1963, p. 180; Irimura, 1969, p. 45; A.M. Glark \& Rowe, 1971, p. 125; Cherbonnier \& Guille, 1978, p. 217, pl. XV, figs. 5 \& 6; Irimura, 1979, p. 5; Sloan, A.M. Clark \& Tayber, 1979, p. 111.

Material examined: Seto, under boulder at low tide level, July 30, 1928 (Oph. 47). Other record: Seto, (Murakami 1963).

Distribution: West of Cape Inubo, Japan Sea, southerly to Indo-West Pacific. Remarks: Color: Specimens from the Japanese waters are generally dark in coloration, dark gray or dark chocolate, sometimes with lighter patches dorsally; arms with darker and lighter annulations.

\section{Ophiarachnella differens Murakami}

(Jap. name: Itsutsume-kumohitode)

Ophiarachnella diffrens Murakami, 1944b, p. 270, fig. 3.

Material examined: Hatakejima, under boulder at low tide level, Apr. 4, 1954. (Oph. 57); Seto, under boulder at low tide level, July 31, 1968 (Oph. 76).

Distribution: Amakusa Is., Goto Is.

Remarks: Color: dirty gray, with dark and white spots on the disk; arms with rusty bands.

\section{Ophiarachna incrassata (Lamarck)}

(Jap. name: Oh-kumohitode)

Ophiura incrassata Lamarck, 816, p. 542.

Ophiarachna incrassata Müller \& Troschel, 1842, p. 104; Lyman, 1874, p. 221: 1882, p. 173; Brock, 1888, p. 495; Koehler, 1905, p. 64; H.L. Clark, 1908, p. 298: 1909, p. 128; Matsumoto, 1917, p. 318, fig. 88; Murakami, 1943b, p. 211; H.L. CLARK, 1921, p. 140, pl. XXXIV, figs. 1 \& 2; Koehler, 1930, p. 271.

Material examined: Off Minabe, by fishing net, Dec. 28, 1970 (Oph. 90). Distribution: West of Kii Peninsula, southerly to Indo-West Pacific area.

Remarks: Color: scarlet both dorsally and ventrally, with white spots on oral shields and ventral arm plates. 


\section{Ophiarachna ohshimai Murakami}

(Jap. name: Ohshima-kumohitode)

Ophiarachna ohshimai Murakami, 1943b, p. 211, fig. 1.

Material examined: Tanabe Bay, by dredge, June 28, 1957 (Oph. 79).

Distribution: Ishigaki-jima, in the Yaeyama Archpelago.

Remarks: Color: deep grayish olive.

\section{Pectinura anchista H. L. Clark}

(Jap. name: Menashi-kumohitode)

Pectinura anchista H.L. Glark, 1911, p. 23, fig. 1; Matsumoto, 1917, p. 322; Murakami, 1942, p. 33; Irimura, 1979, p. 5.

Material examined: Tanabe Bay, ca. $80 \mathrm{~m}$ deep, by dredge, July 28, 1957 (Oph 7). Distribution: Sagami Bay, Kagoshima Bay, Sado Is., East China Sea.

Remarks: Color: reddish brown dorsally.

\section{Family Ophiocomidae Ljungman, 1867}

\section{Ophiocoma dentata Müller \& Troschel}

(Jap. name: Gomafu-kumohitode)

Ophiocoma dentata Müler \& Troschel, 1842, p. 99 pl. 7, figs. 3 \& 3a; Lutken, 1859, p. 267; Lyman, 1865, p. 70; H.L. Clark, 1921, p. 121; Koehler, 1922, p. 314; Devaney, 1970, p. 13, figs. 17-19 \& 21: 1974, p. 153.

Ophiocoma insularia Lyman, 1861, p. 80: 1865, p. 89: 1874, p. 225; H.L. Clark, 1915, p. 291, pl. 15, figs. 3 \& 4; Ely, 1942, p. 57, fig. 17, pl. 13a.

Ophiocoma ternispina Martens, 1870, p. 252; Lyman, 1874, p. 225.

Ophiocoma brevipes Lyman, 1874, p. 225: 1882, p. 172 (par); Loriol, 1894, p. 25, pl. 23, figs. 4 \& 4a; Matsumoto, 1917, p. 343, figs. 3a-c. (non Peters).

Ophiocoma varregata Smith, 1876, p. 39: 1879, p. 565, pl. 51, figs. 1-1c.

Cphiocoma marmorata Marktanner-Turneretscher, 1887, p. 303, pl. 12, figs. 16 \& 17; H.L. Clark, 1915, p. 294.

Ophiocoma brevipes var. variegata H.L. Clark, 1921, p. 130.

Ophiocoma brevipes var. insularia H.L. Clark, 1921, p. 130.

Ophiocoma insularia var. variegata H.L. Clark, 1938, p. 330: 1939, p. 94; Ely, 1942, p. 60, pl. 13, fig. B; H.I. Clark, 1946, p. 246; Endean, 1957, p. 244; Domantay \& Domantay, 1966, p. 53.

Material examined: Seto, under boulder at low tide level, July 31, 1968 (Oph. 34); Seto, under boulder at low tide level, Aug. 5, 1970 (Oph. 80).

Distribution: Sagami Bay, southerly to the Indo-West Pacific area.

Remarks: The specimen, Oph. 34, is chocolate dorsally and with dark spots on the disk, and dorsal arms are annulated with darker and lighter bands. This color pattern is commonly seen in the specimens from the temperate Japanese coasts. The specimen, Oph. 80, is black dorsally and with lighter spots on the dorsal disk. 


\section{Ophiomastix mixta Lütken}

(Jap. name: Aka-kumohitode)

Ophiomastix mixta Lütken, 1869, p. 44; Lyman, 1882, p. 175; Brock, 1882, p. 497; Loriol, 1893, p. 414; Koehler, 1905, p. 68, pl. IV, fig. 15, pl. XV, fig. 1; H.L. Clark, 1911, p. 256, fig. 126; Matsumoto, 1917, p. 348, fig. 97; H.L. Clark, 1921, p. 135, pl. 14, fig. 2; Koehler, 1922, p. 330; Murakami, 1944b, p. 277; Endean, 1956, p. 126; Murakami, 1963, p. 180; A.M. Clark \& Rowe, 1971, p. 120; Devany, 1978, p. 319, figs. 21 \& 22.

Material examined: Seto, under boulder at low tide level, Apr. 26, 1928 (Oph. 8) and Apr. 9, 1959 (Oph. 11); Hatake-jima, under boulder at low tide level, Apr. 11, 1951 (Oph. 20).

Distribution: West of Tokyo Bay, Japan; Philippines; Amboina; North Australia; South Pacific.

Remarks: Color: red.

\section{Family Ophionereidae Lütken, 1859}

\section{Ophionereis dubia (Müller \& Troschel)}

(Jap. name: Amime-kumohitode)

Ophiolepis dubia Muller \& Troschel, 1842, p. 94.

Ophionereis dubia von Marten, 1870, p. 246; A.M. Glark, 1953, p. 83, pl. 2, figs. 1 \& 2, text-figs. 9 \& 10; Domantay \& Domantay, 1966, p. 47; Irimura, 1969, p. 46; A.M. Clark \& Rowe, 1971, p. 122, fig. 40a; A.M. Clark \& Courtman-Stock, 1976, p. 124, fig. 193; A.M. Clark \& C.M. Clark, 1976, p. 128; Cherbonnier \& Guille, 1978, p. 203, fig. 67; Irimura, 1979, p. 5; Sloan, A.M. Glark \& Tayler, 1979, p. 111.

Ophionereis dubia var sinensis Duncan, 1879, p. 175, fig. 79.

Ophiocrasis marktanneri Matsumoto, 1915, p. 90: 1917, p. 338, fig. 94; Murakami, 1942, p. 34: 1944b p. 227.

Ophionereis stigma H.L. Glark, 1938, p. 325: 1946, p. 239.

Ophionereis latens Murakami, 1944b, p. 275, fig. 5.

Material examined: Seto, under boulder at low tide level, Aug. 31, 1968 (Oph. 28); Koza in Gobo, $4 \mathrm{~m}$ deep, under boulder on rocky bed, May 3, 1978.

Distribution: West of Sagami Bay, Japan Sea, southerly to the Indo-West Pacific area.

Remarks: Color: pale yellow or grayish yellow green, with a reddish reticulation on the dorsal disk; the dorsal side of arms with an annulation consisting of alternating reddish purple and pale yellow bands.

\section{Ophionereis variegata Duncan}

(Jap. nane: Sanmen-kumohitode)

Ophionereis variegata Duncan, 1879, p. 462, pl. 10, figs. 15 \& 16; A.M. Glark, 1953, p. 81, fig. 7.

Ophionereis' 'porrecta Matsumoto, 1917, p. 334, fig. 93; Murakami, 1942, p. 34: 1944b, p. 274 (non o. porrecta Lyman). 
Material examined: Hirashima in Gobo, $3 \mathrm{~m}$ deep, under boulder, May 4, 1978. Distribution: Sagami Sea, Amakusa, Korea Strait.

Remarks: Color: pale brown or grayish yellow dorsally, dorsal arms with darker and lighter annulatins.

\section{REFERENCES}

Chan, F.Y., Liao, Y.L. \& Wu, B.L. 1962. Euryalae of the China Sea. Acta Zool. sin. 14: 53-68, 2 figs, 4 pls. (In Chinese with Russian summary)

Cherbonnier, G. \& Guille. A. 1978. Fauna de Madagascar. (Paris). 253pp. 77 figs. 17, pls.

Clark, A.M. 1953b. A revision of the genus Ophionereis. Proc. zool. Soc. London. 123 (1): 65-94, 12 figs, 3 pls.

Clark, A.M. 1965. Japanese and other ophiuroids from the collection of the Munich Museum. Bull. Br. Mus. nat. Hist. (Zool) 13 (2): 33-71, 6 figs. 1 pl.

Clark, A.M. 1967b. Notes on the family Ophiotrichidae (Ophiuroidea). Ann. Mag. nat. Hist. 9: 637-655, 1 fig, 2 pls.

Clark, A.M. 1968. Notes on some tropical Indo-Pacific Ophiotrichids and Ophiodermatids (Ophiuroidea). Bull. Br. Mus. nat. Hist. (Zool). 16 (7): 275-322, 10 figs, 1 pl.

Clark, A.M. 1970. Notes on the family Amphiuridae (Ophiuroidea). Bull. Br. Mus. nat. Hist. (Zool). 19 (1) : 1-81, 2 figs.

Clark, A.M. \& Rowe, F.W.E. 1971. Shallow-water Indo-West Pacific Echinoderms. (London). 238pp, 100 figs, 31 pls.

Clark, A.M. \& Courtman-Stock, J. 1976. The Echinoderms of South Africa. (London). 277 pp, 276 figs.

Clark, H.L. 1911. North Pacific ophiurans in the collection of the United States National Museum. Bull. U.S. Nat. Mus 75: 1-302, 144 figs.

Clark, H.L. 1915. Catalogue of recent ophiurans. Mem. Mus. comp. Zool. Harvard. 25: 165-376, $20 \mathrm{pls}$.

Glark, H.L. 1938. Echinoderms from Australia. Mem. Mus. comp. Zool. Harvard. 55: viii $+596,63$ figs, 28 pls.

Clark, H.L. 1946. The Echinoderm fauna of Australia. Publ. Carnegie Inst. 566: 1-567.

Devaney, D.M. 1970. Studies on ophiocomid brittlestars. I. A new genus (Clarkcoma) of Ophiocominae with a re-evaluation of the Ophiocoma. Smithson. Contrib. Zool. 51: 1-41, 50 figs.

Devaney, D.M. 1974. Shallow-water asterozoans of Southern Polynesia. II. Ophiuroidea. Micronesica $10(1): 105-204,25$ figs.

Devaney, D.M. 1978. A review of the genus Ophiomastix (Ophiuroidea). Micronesica. 14 (2): 273-359, 42 figs.

Döderlein, L. 1911. Uber japanische und anderes Euryalae. Abh. bayer. Akad. Wiss., 2 (5): 1-123, 9 pls.

Döderlein, L. 1927. Indopacifische Euryalae. Abh. bayer. Akad. Wiss. 31 (6): 1-105, 10 pls.

Dömantay, J.S. \& Domantay, C.R. 1967. Studies on the classification and distribution of Philippine littoral Ophiuroidea. Philippine J. Sci., 95 (1): 1-76, 2 pls.

Duncan, P.M. 18979. On some Ophiuroidea from Korean Seas. J. Linn. Soc. Zoc., 14: 445-482, 3 pls.

D'yakonov, A.M. 1954. Ofiury morei SSSR. Opred. Faune SSSR, 55: 1-136, 47 figs. (in Russian)

Fell, H.B. 1960. Synoptic key to the genera of Ophiuroidea. Zool. Pub. Victorria Univ., Wellington, 26: $1-44$.

Fell, H.B. 1962. A revision of the major genera of Amphiurid, Ophiuroidea. Trans. Roy. Soc. New Zealand (Zool), 2 (1): 1-26, 1 pl.

Guille, A \& Jangoux, M. 1978. Astérides et Ophiurides littorales de la region d'Amboine (Indonesie). Ann. Inst. oceanogr., Paris. 54 (1): 47-74, 9 figs.

Hayashi, K. 1975. Occurrences of the crown-of thorns starfish, Acanthaster planci (L), along the southern coast of Kii Peninsula, Japan. Bull. Mar. Park Res. St., 1 (1): 1-9. 
Irimura, S. 1967. A new species of Ophiuroidea from the coast of Kii Peninsula, Japan. Publ. Seto Mar. Biol. Lab., 15(5) : 353-356, 1 fig.

Irimura, S. 1969. Supplemental report of Dr. Murakami's paper on the ophiurans Amakusa, Kyushu. Publ. Amakusa Mar, Biol. Lab., Kyushu Univ., 2 (1): 37-48, 4 pls.

Irimura, S. 1979. Ophiuroidea of Sado Island, the Sea of Japan. Ann. Rep. Sado Mar Biol. St., 9: 1-6.

Koehler, R. 1898. Echinodermes recueillis par 1'Investigator dans 1'Ocran Indien. II. Les Ophiures littorales. Bull. Sci. France et Berg., 31, 54-124, 5 pls.

Koehler, R. 1904a. Ophiures de mer profonde. Siboga-Exped., Mon., 45a: 1-176, 36 pls.

Koehler, R. 1904b. Ophiures nouvelles ou peu connues. Mem. Soc. Zool. France. 7: 54-119, 98 figs.

Koehler, R. 1905. Ophiures littorales. Siboga Exped., 45b: 1-422, 18 pls.

Koehler, R. 1922. Ophiurans of the Philippine Sea and adjacent waters. Bull. U.S. Nat. Mus. 100 (5) : 1-486, 103 pls.

Koehler, R. 1930. Ophiures recueillis par le doc. Th. Mortensen dans les mers d'Australie et dans 1'Archipel Malais. Vidensk. Meddr dansk naturh. Foren. 89: 1-295, 22 pls.

Lamarck, J.B.P.A. de. 1816. Histoire naturelle des animaux sans vertebres. (Paris) Ed. I. 2: 522568.

Liao, Y. 1978. The Echinoderms of the Xisha Island, Guangdong Province, China. II. Ophiuroidea. Inst. Oceanogr. Acad. Sinica. 386:69-102, 4 pls.

Loriol, P. de. 1893a. Catalogue raisonné des Echinoderms recueillis par M.V·de Robillard à l'Ile Maurice. III. Ophiurides et Astrophytides. Mem. Soc. Phys. Hist. nat. Genève. 32 (3): 1-63, 3 pls.

Lyman, T. 1878. Ophiuridae and Astrophytidae of the Challenger Expedition. Pt. I. Bull. Mus. comp. Zool. Harvard. 7: 65-168, 10 pls.

Lyman, T. 1979. Ophiuridae and Astrophytidae of the Challenger Expedition. Pt. II. Bull. Mus. comp. Zool. Harvard. 6 (2): 17-83, 8 pls.

Lyman, T. 1882. Report on the Ophiuroidea dredged by the Challenger. The voyage of the Challenger. (zool). 5: 1-386, 46 pls.

Marktanner-Turneretscher, G. 1887. Beschreibung neur Ophiuriden und Bemerkungen zu Bakkanten. Ann. naturh. Mus. Wien. 2: 291-316, 2 pls.

Martens, E. von. 1867b. Ucber vier neue Schlangensterne (Ophiuren) des Kgl. zoologischen Museums. Mber. dt. Akad. Wiss. Berlin. 1867: 345-348.

Martens, E. von. 1870. Die Ophiuriden des indischen Oceans. Arch. Naturgesch. 36: $245-262$.

Matsumoto, H. 1915. A. new classification of the Ophiuroidea, with descriptions of new genera and species. Proc. Akad. Nat. Sci. Philadelphia, 67 : 43-92.

Matsumoto, H. 1917. A monograph of Japanese Ophiuroidea, arranged according to a new classification. J. Coll. Sci. Imp. Univ. Tokyo. 38 (2): 1-408, 52 pls.

Matsumoto, H. 1941. Report of the biological survey of Mutsu Bay. Sci. Rep. Tohoku Imp. Univ.: Ser. 4 (Biol.), 16 (3): 331-344, 3 pls.

Mortensen, T. 1933a. Studies of Indo-Pacific Euryalids. Vid. Med. naturh. For. Kbh., 96: 1--75, 5 pls.

Mortensen, T. 1934. Echinoderms of Hong Kong. Hong Kong Nat. Suppl., 3.: 1-14, 8 pls.

Müller, J. \& Troschel, F.H. 1842. System der Asteriden. Braunschweig: XX $+134,12$ pls.

Murakami, S. 1942. Ophiurans of Izu, Japan. J. Dept. Agr., Kyushu Imp. Univ., 7 (1): 1-36, 12 fis.

Murakami, S. 1943b. Report on the ophiurans of Yaeyama, Ryukyu. Ditto. 7 (5): 205-222, 2 figs.

Murakami, S. 1943c. Ophiurans from some gulfs and Bays of Nippon. Ditto, 7 (7): 223-234, 2 figs.

Murakami, S. 1944b. Notes on the ophiurans of Amakusa, Kyushu. Ditto. 7 (7): 259-279, 1 pl.

Murakami, S. 1963. On some ophiurans from Kii and vicinities with description of a new species, Publ. Seto Mar. Biol. Lab. 11 (2): 171-184, 1 fig.

Sloan, N.A., Clark, A.M. \& Tayler, J.D. 1979. The echinoderms of Aldabra and their habitats. Bull. Br. Mus. Nat. Hist. (Zool.) 37 (2): 81-128, 22 figs. 


\section{EXPLANATION OF PLATE I.}

Fig. 1. Asteroporpa hadrachantha (Oph. 95).

Fig. 2. Astroceras annulatum (Oph. 98) and Asteroporpa hadracantha (Oph. 97).

Fig. 3. Astroceras annulatum (Oph. 96) five arm specimen.

Fig. 4. Ophiothrix exigua (Oph. 86) sponge broke. 


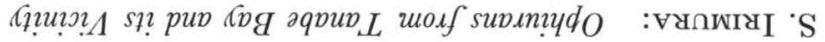
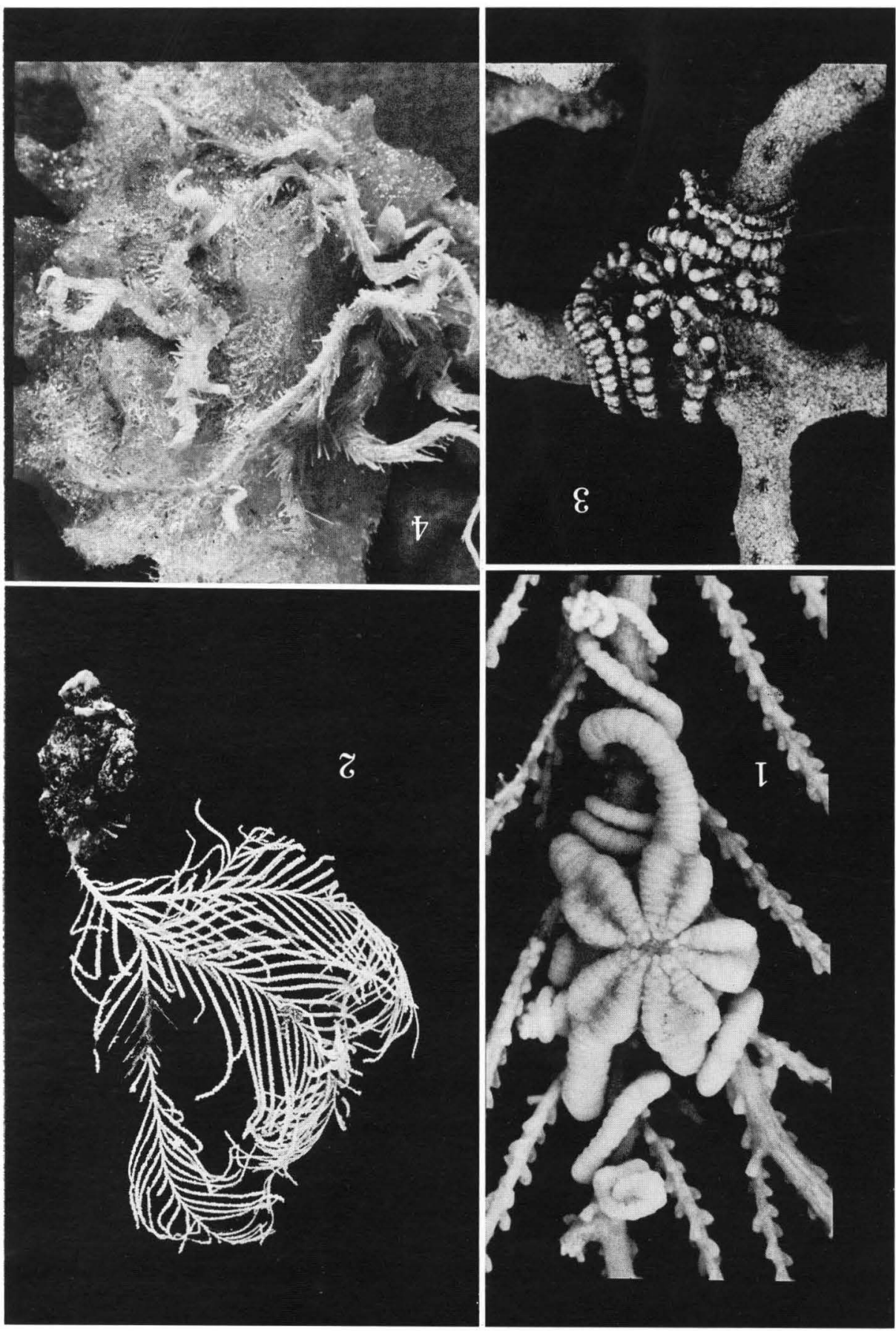

I GLVTd

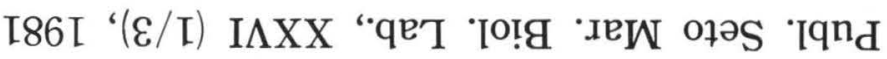

